\title{
Conceptual feasibility studies for cost-efficient and bi-functional methylcyclohexane dehydrogenation in a membrane reactor for $\mathrm{H}_{2}$ storage and production
}

\author{
Manhee Byun, Heehyang Kim, Changgwon Choe, Hankwon Lim \\ School of Energy and Chemical Engineering, Ulsan National Institute of Science and Technology, 50 UNIST-gil, Eonyang-eup, Ulju-gun, Ulsan 44919, Republic of Korea
}

\section{A R T I C L E I N F O}

\section{Keywords:}

Methylcyclohexane dehydrogenation

$\mathrm{H}_{2}$ production

Membrane reactor

Techno-economic analysis

Process simulation

Carbon footprint analysis

\begin{abstract}
A B S T R A C T
As the global trend towards transition to a "hydrogen society" continues to gain momentum, a lot of studies on alternative hydrogen $\left(\mathrm{H}_{2}\right)$ production methods are on the rise. Among them, methylcyclohexane (MCH) dehydrogenation in a membrane reactor (MR) is reported here as one possible candidate, affording its enhanced $\mathrm{H}_{2}$ yield and a compact design. In this study, techno-economic analysis and carbon footprint analysis (CFA) of MCH dehydrogenation in an MR are carried out to investigate economic and environmental feasibility providing techno-economic and environmental guidelines for realizing it as mature technology. The economic parameters are determined through process simulation using Aspen Plus ${ }^{\circledR}$, and the unit $\mathrm{H}_{2}$ production costs are obtained for a packed-bed reactor (PBR) and an MR in $\mathrm{H}_{2}$ production capacities of 30,100,300, and $700 \mathrm{~m}^{3} \mathrm{~h}^{-1}$. The effects of each economic parameter on the unit $\mathrm{H}_{2}$ production cost are identified through sensitivity analysis (SA) and scenario analysis is performed under various conditions to investigate the effects of technical parameters of the membrane, such as the $\mathrm{H}_{2}$ production capacity, temperature, and $\mathrm{H}_{2}$ permeance on the unit $\mathrm{H}_{2}$ production costs. CFA is also performed to investigate the environmental feasibility of $\mathrm{MCH}$ dehydrogenation in an MR by considering $\mathrm{CO}_{2}$ emissions at each part.
\end{abstract}

\section{Introduction}

As environmental concerns about global warming due to the consumption of fossil fuel continue to escalate, renewable energy has received more attention as a green energy source $[1,2]$. In the generation of energy from renewable sources such as solar, wind, and hydro power, there is an inevitable mismatch between the power demand and supply due to the seasonal and spatial characteristics of these resources $[3,4]$. Thus, the surplus electricity resulting from this mismatch is expected to be used for hydrogen $\left(\mathrm{H}_{2}\right)$ production [5,6]. The global demand for $\mathrm{H}_{2}$ has increased continuously by $3-4 \%$ annually [7] and $\mathrm{H}_{2}$ continues to receive attention as a clean alternative energy carrier based on the fact that it only produces water as a byproduct upon conversion to energy compared to conventional fuel such as natural gas, petroleum, and coal [8]. $\mathrm{H}_{2}$ has many advantages as an energy carrier; for example, it is (a) most abundant element accounting for more than $90 \%$ of all atoms in the universe, (b) very light with a molecular weight of $2.016 \mathrm{~g} \mathrm{~mol}^{-1}$, (c) sustainable, and (d) easily integrated with conventional electric and natural gas infrastructrue; (e) it has a high energy density of 120-142
MJ kg ${ }^{-1}$ [9-11]. With these advantages of $\mathrm{H}_{2}$ as an alternative energy carrier, worldwide efforts to transition to a " $\mathrm{H}_{2}$ society" have been on the rise $[12,13]$.

Conventionally, $\mathrm{H}_{2}$ is produced by steam reforming, partial oxidation, auto-thermal reforming, and $\mathrm{CO}_{2}$ reforming of non-renewable fossil-fuels like natural gas, coals, and heavy oils [14,15]. Among them, methane steam reforming is the most commercialized $\mathrm{H}_{2}$ production method, accounting for $48 \%$ of global $\mathrm{H}_{2}$ production $[16,17]$. However, $\mathrm{H}_{2}$ production processes based on fossil fuel resources have associated drawbacks related to environmental issues and depletion of resources, leading the development of alternative $\mathrm{H}_{2}$ production methods $[18,19]$. Notably, methane steam reforming requires a very large amount of heat, emits large amounts of $\mathrm{CO}_{2}$, and requires $\mathrm{H}_{2}$ purification equipment such as pressure swing adsorption (PSA) resulting in high costs $[20,21]$. To overcome these challenges, many studies on steam reforming using alternative feedstocks such as methanol, ethanol, and ethane, under relatively milder reaction conditions, have been conducted [22-24]. However, these methods still suffer from greenhouse gas $\left(\mathrm{CO}_{2}\right)$ emissions during the reactions.

In this context, methylcyclohexane (MCH) dehydrogenation, repre-

\footnotetext{
* Corresponding author.

E-mail address: hklim@unist.ac.kr (H. Lim).
} 


$\begin{array}{ll}\text { Nomenclature } \\ \mathrm{H}_{2} & \text { Hydrogen } \\ \text { PSA } & \text { Pressure swing adsorption } \\ \mathrm{MCH} & \text { Methylcyclohexane } \\ \mathrm{MR} & \text { Membrane reactor } \\ \mathrm{PBR} & \text { Packed-bed reactor } \\ \text { TOL } & \text { Toluene } \\ \text { LOHC } & \text { Liquid organic hydrogen carrier } \\ \text { SA } & \text { Sensitivity analysis } \\ \text { HFMR } & \text { Hollow fiber membrane reactor } \\ \text { LHSVs } & \text { Liquid hourly space velocities } \\ \text { rms } & \text { Root-mean-square } \\ \text { BFD } & \text { Block flow diagram } \\ \text { OPEX } & \text { Operating expenditure } \\ \text { DOE } & \text { Department of Energy } \\ \text { FCI } & \text { Fixded capital investment } \\ \text { CEPCI } & \text { Chemical engineering plant cost index } \\ \text { CRF } & \text { Capital recovery factor }\end{array}$

sented by Eq. (1), has been introduced as an alternative $\mathrm{H}_{2}$ production method with no emission of $\mathrm{CO}_{2}$ and only toluene (TOL) and $\mathrm{H}_{2}$ as products, with a relatively low reaction temperature of 573-673 K [25].

$\mathrm{CH}_{3} \mathrm{C}_{6} \mathrm{H}_{11} \rightarrow \mathrm{CH}_{3} \mathrm{C}_{6} \mathrm{H}_{5}+3 \mathrm{H}_{2} \quad \Delta \mathrm{H}=205 \mathrm{~kJ} \mathrm{~mol}^{-1}$

$\mathrm{MCH}$ is also a very strong candidate as a liquid organic hydrogen carrier (LOHC), and the MCH dehydrogenation process has the following advantageous characteristics: (a) high $\mathrm{H}_{2}$ content of $47.3 \mathrm{kgH}_{2}$ $\mathrm{m}^{-3}$ or $6.0-7.5 \mathrm{wt} \%$; (b) ease to transport or store the product as it is in the liquid state at ambient temperature and pressure; (c) no freezing process is required in the plants due to the very low freezing temperature of $-126.6{ }^{\circ} \mathrm{C}$ for $\mathrm{MCH}$ and $-95{ }^{\circ} \mathrm{C}$ for TOL; the process is (d) highly reversible and (e) selective; (f) the products are non-carcinogenic; the process $(\mathrm{g})$ does not emit $\mathrm{CO}_{2}$ and $(\mathrm{h})$ produces TOL as a recyclable and eco-friendly product; (i) the physical/chemical properties of the product are similar to those of gasoline [26-30].

Even though $\mathrm{MCH}$ dehydrogenation can be treated as an eco-friendly $\mathrm{H}_{2}$ production method, it still requires a large amount of heat, which can lead to huge $\mathrm{CO}_{2}$ emissions in supplying this heat. Thus, a membrane reactor (MR), which incorporates $\mathrm{H}_{2}$ separation membrane into conventional reactor, can be used to improve the feedstock conversion and $\mathrm{H}_{2}$ production yield naturally, thereby reducing the required heat
$[31,32]$ and avoiding the additional purification step resulting in cost reduction [33].

Fig. 1 shows a schematic diagram of the overall $\mathrm{H}_{2}$ supply chain using LOHC. In this supply chain, the novel concept of utilizing MR for $\mathrm{MCH}$ dehydrogenation is presented to achieve the benefits of higher reactant conversion, production yield, and a lower reaction temperature based on the equilibrium shift due to Le Chatelier's principle [34,35]. In addition, a more compact design can be achieved because the reactor unit and $\mathrm{H}_{2}$ separator are merged in an MR [36].

Recent studies have shown the advantages of MCH dehydrogenation in an MR using a $\mathrm{H}_{2}$ membrane. Kreuder et al. [37] investigated the membrane separation performance of a Pd-membrane in terms of its ability to shift the equilibrium to the product side during $\mathrm{MCH}$ conversion and reported a higher $\mathrm{MCH}$ conversion of about $97 \%$ compared to the equilibrium conversion of about 78\%. Hatim et al. [38] developed a $\mathrm{Pd} / \mathrm{Al}$ hollow fiber membrane reactor (HFMR) consisting of a Pd membrane (with no defects) on the surface of an Al hollow fiber substrate. The authors reported a significant increase in the gas permeation resistance when the catalyst loading was above $2.3 \mathrm{mg} \mathrm{cm}^{-1}$ and $\mathrm{MCH}$ conversion of $25 \%, 26 \%$, and $50 \%$ for a fixed-bed reactor, HFMR, and porous membrane reactor, respectively, demonstrating the improved $\mathrm{MCH}$ conversion in the MR. Li et al. [39] reported that an organic silica membrane prepared by sol-gel treatment had $\mathrm{a} \mathrm{H}_{2}$ permeance of $1.29 \times$ $10^{-6} \mathrm{~mol} \mathrm{~m}^{-2} \mathrm{~s}^{-1} \mathrm{~Pa}^{-1}$ and selectivities of 6,680 and 48,900 for $\mathrm{H}_{2} /$ $\mathrm{C}_{3} \mathrm{H}_{8}$ and $\mathrm{H}_{2} / \mathrm{SF}_{6}$ and reported a very high $\mathrm{H}_{2}$ purity of $100 \%$ upon extraction and a higher $\mathrm{MCH}$ conversion (78\%) than the equilibrium conversion. Chen et al. [40] investigated the effects of the feed flow of $\mathrm{MCH}$, catalyst loading, and pressure at the permeate channel on the reactor performance, and the effects of the pore size, based on microscopic scale simulations. They reported that an $\mathrm{MCH}$ conversion of $100 \%$ could be achieved at $543.15 \mathrm{~K}$ with feed molar flow of $3 \times 10^{-6}$ mol s${ }^{-1}$, catalyst loading of $70.74 \mathrm{~kg} \mathrm{~m}^{-3}$, and pressure of $1.013 \mathrm{bar}$ and $0.1 \mathrm{bar}$ for the retentate and permeate channels, respectively. Ali et al. [41] also developed a pilot-scale membrane reactor with a sulfided Pt/ $\mathrm{Al}_{2} \mathrm{O}_{3}$ catalyst and a $0.1 \mathrm{~mm} \mathrm{Pd}_{77} \mathrm{Ag}_{23}$ membrane and optimized liquid hourly space velocities (LHSVs) of $1.65,1.05$, and $0.97 \mathrm{~h}^{-1}$ at 643,613 , and $593 \mathrm{~K}$, respectively.

In addition to the experimental studies, some researchers reported both experimental and theoretical studies. Li et al. [42] conducted an experimental and theoretical study of $\mathrm{MCH}$ dehydrogenation in a catalytic MR composed of a $\mathrm{Pt} / \gamma-\mathrm{Al}_{2} \mathrm{O}_{3} / \alpha-\mathrm{Al}_{2} \mathrm{O}_{3}$ catalytic support and silica $\mathrm{H}_{2}$ separation layer, and reported that the $\mathrm{H}_{2}$ permeance of the silica membrane was $(1.51-2.83) \times 10^{-6} \mathrm{~mol} \mathrm{~m}^{-2} \mathrm{~s}^{-1} \mathrm{~Pa}^{-1}$ with a $\mathrm{H}_{2} / \mathrm{SF}_{6}$ permeance ratio of $290-1000$ at $473 \mathrm{~K}$. They reported significantly enhanced $\mathrm{MCH}$ conversion (82\%) with $\gamma-\mathrm{Al}_{2} \mathrm{O}_{3}$ compared to that of

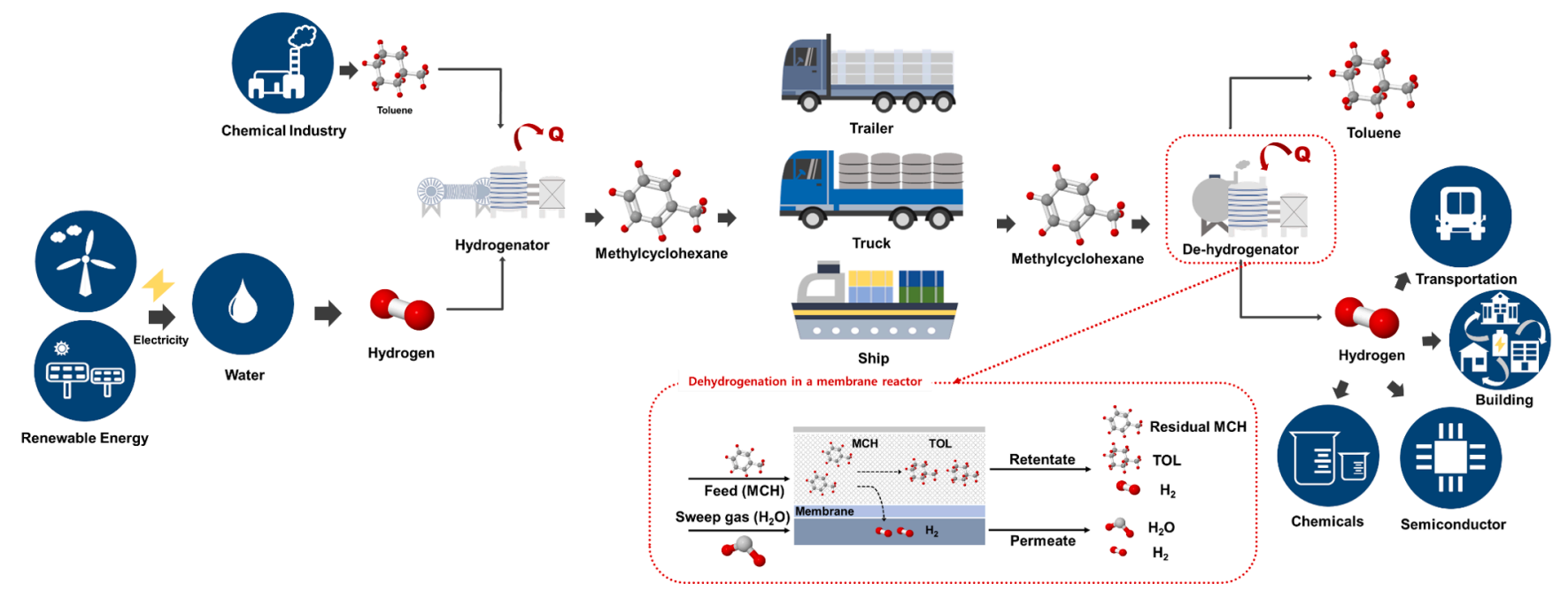

Fig. 1. Schematic diagram of an overall hydrogen supply chain using a membrane reactor (MR) with liquid organic hydrogen carrier (LOHC). 
(11\%) without $\gamma-\mathrm{Al}_{2} \mathrm{O}_{3}$. Cholewa et al. [43] experimentally investigated the performance of an MR with Pd foils and the effect of the microstructure of the membrane module with catalyst and conducted simulation to optimize the modules. Their results showed that when the pressure was up to 30 bar and 3 bar at the start for the retentate and permeate sides, an $\mathrm{MCH}$ conversion of $90 \%$ and $\mathrm{H}_{2}$ recovery of about $80 \%$ were obtained. Oda et al. [44] developed an MR with an amorphous silica membrane, with a $\mathrm{H}_{2}$ permeance of the order of $10^{-6} \mathrm{~mol}$ $\mathrm{m}^{-2} \mathrm{~s}^{-1} \mathrm{~Pa}^{-1}$ and $\mathrm{H}_{2} / \mathrm{SF}_{6}$ selectivity of around $10^{4}$. A Pt/ $\mathrm{Al}_{2} \mathrm{O}_{3}$ catalyst was used for their study and they also simulated the system in the temperature range of $473-553 \mathrm{~K}$ and reaction pressure range of 0.1-0.25 MPa and confirmed a high $\mathrm{H}_{2}$ purity of $99.95 \%$ with no carrier gas or sweep gas.

Despite the numerous experimental and theoretical studies, no techno-economic approaches have been reported thus far, to the best of our knowledge. However, economic feasibility study beyond the laboratory-scale should be undertaken to realize commercialization of premature technology and to suggest its direction for further research and the objective of this study is to provide practical guidelines for $\mathrm{MCH}$ dehydrogenation in an MR in both economic and environmental perspectives. Therefore, techno-economic and carbon footprint analysis (CFA) of MCH dehydrogenation for various $\mathrm{H}_{2}$ production capacities of $30,100,300$, and $700 \mathrm{~m}^{3} \mathrm{~h}^{-1}$ are conducted in this study to evaluate the technical and economic viability of the process. The economic parameters are determined from process simulation using Aspen Plus ${ }^{\circledR}$ and the $\mathrm{H}_{2}$ production cost is determined from itemized cost estimation based on these parameters. Sensitivity analysis (SA) is carried out to determine the key economic parameter and identify the effects of each parameter. In addition, to understand the effects of each parameter on the unit $\mathrm{H}_{2}$ production cost, scenario analysis regarding the $\mathrm{H}_{2}$ production capacity, temperature, and $\mathrm{H}_{2}$ permeance is performed. The environmental feasibility of the process is investigated through carbon footprint analysis by comparing the $\mathrm{CO}_{2}$ flow rates from both a packed-bed reactor (PBR) and an MR. Through those conceptual feasibility studies, comprehensive direction which MCH dehydrogenation in an MR should have to take in order to realize economic feasibility was proposed.

\section{Methods}

\subsection{Process simulation}

MCH dehydrogenation in a PBR and an MR was simulated in Aspen Plus ${ }^{\circledR}$ (Aspen Technology, Inc., Bedford, MA, USA) by using Gibbs

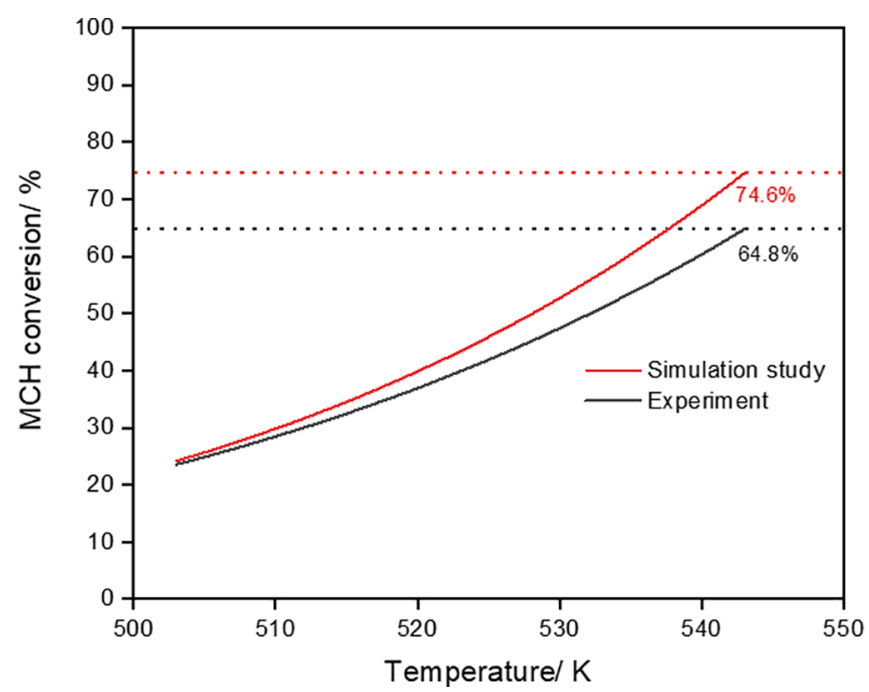

Fig. 2. Model validation of simulation results with experimental ones reported by Meng et al. [45]. reactor for model validation.

Fig. 2 compares the simulated MCH conversion at 503-543 K, obtained from process simulation using the experimental results reported by Meng et al. [45], demonstrating a reasonable match and this Gibbs reactor is employed for both a PBR and an MR to ensure a fair comparison. This slight difference between the simulated and experimental results arises several assumptions such as that Gibbs reactor is isothermal and isobaric; nevertheless, the agreement is adequate for further parametric study.

Fig. 3 presents the block flow diagram (BFD) for MCH dehydrogenation in a PBR and an MR, respectively. Isothermal and isobaric reactions in Gibbs reactor with the Peng-Robinson equation of state, which can handle large reaction temperature and pressure range and is known as a suitable fluid package for hydrocarbon, air, and water, etc. [46], were assumed for the simulation. Compared to the PBR unit consisting of only Gibbs reactor, a template unit composed of Gibbs reactors to simulate $\mathrm{H}_{2}$ production through MCH dehydrogenation and separators to reflect $\mathrm{H}_{2}$ separation through membrane based on several parameters of $\mathrm{H}_{2}$ permeance, membrane area, and $\mathrm{H}_{2}$ partial pressure difference was constructed for MR to reflect the effects of hydrogen separation through the membrane [47]. Additionally, a boiler unit using natural gas combustion with $20 \%$ excess oxygen was also constructed to consider heat required for an endothermic $\mathrm{MCH}$ dehydrogenation reactor in the economic analysis. Based on the physical properties of the $\mathrm{Pt} / \gamma-\mathrm{Al}_{2} \mathrm{O}_{3} /$ $\alpha-\mathrm{Al}_{2} \mathrm{O}_{3}$ catalysts and the organosilica $\mathrm{H}_{2}$ separation membrane, reported by Meng et al. [45], improved $\mathrm{H}_{2}$ permeance in the range of from $5 \times 10^{-7}$ to $5 \times 10^{-4} \mathrm{~mol} \mathrm{~m}^{-2} \mathrm{~s}^{-1} \mathrm{~Pa}^{-1}$ and infinite selectivity were assumed.

\subsection{Itemized cost estimation}

The unit $\mathrm{H}_{2}$ production cost was estimated for a $\mathrm{H}_{2}$ production capacity of $30 \mathrm{~m}^{3} \mathrm{~h}^{-1}$ based on process simulation. The cost estimation methods reported by Turton et al. [48] were used, and the total cost was defined as the sum of the annualized capital cost $\left(\$ y^{-1}\right)$ and operating cost $\left(\$ \mathrm{y}^{-1}\right)$. In this study, the reactor, membrane module, compressor, PSA, and supplement are classified as capital cost; the reactant, PSA OPEX, the sweep gas, electricity, labor, membrane replacement, natural gas, and maintenance, and other costs are classified as operating costs. The cost of the membrane module was estimated as 5,382 $\$ \mathrm{~m}^{-2}$ based on the targeted value from the U. S. Department of Energy (DOE), and the cost of the reactor $\left(30,000,000 €\right.$ for $\mathrm{H}_{2}$ production capacity of 300 ton $\mathrm{d}^{-1}$ ) reported by Reuß et al. [49] was used. The compressor cost was estimated at 15,000 \$ for used electricity of $10 \mathrm{~kW}$ [50] and a cost of 83,091 \$ was calculated for PSA based on the equation reported by Hoffman [51]. The supplement cost was defined as $20 \%$ of the fixed capital investment (FCI), defined as the sum of the reactor, membrane module, compressor, and PSA.

To reflect price fluctuations such as inflation, deflation, etc., the chemical engineering plant cost index (CEPCI, 603.1 of 2019) was used in the estimation of the capital cost, as described by Eq. (2).

$C_{2}=C_{1}\left(\frac{I_{2}}{I_{1}}\right)$

where $C$ is equipment cost, and $I$ is a cost index.

Each capital cost (\$) was converted to the annualized capital cost (\$ $\mathrm{y}^{-1}$ ) by applying the capital recovery factor (CRF) (Eq. (3)).

$\mathrm{CRF}=\frac{i(1+i)^{N}}{(1+i)^{N}-1}$

where $i$ is the discount rate and $\mathrm{N}$ is the economic analysis period.

In this study, $i$ was assumed as 0.045 [52] and $\mathrm{N}$ was 10 years for the compressor, PSA, and membrane module $(\mathrm{CRF}=0.1264)$ and 20 years for the reactor and supplement $(\mathrm{CRF}=0.0769)$. In addition, a stream 


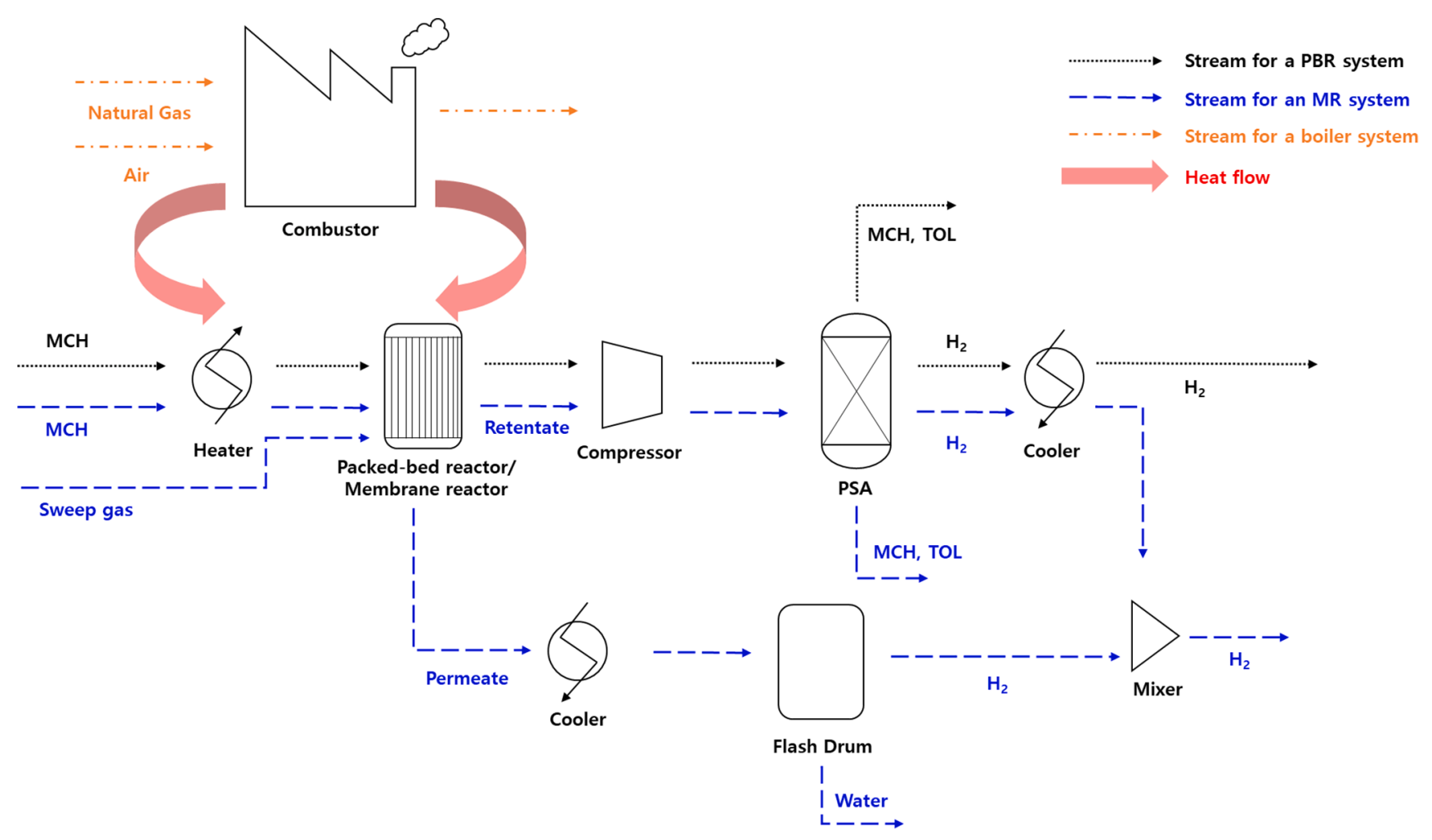

Fig. 3. Block flow diagram (BFD) for methylcyclohexane (MCH) dehydrogenation in a packed-bed reactor (PBR) and a membrane reactor (MR).

factor of 0.93 was assumed and an exchange rate of $\$ 1=1,200 \mathrm{KRW}$ was used. The reactant cost for MCH was $300 \$$ ton $^{-1}$ [53], the water cost was $0.067 \$$ ton $^{-1}$ [47], the PSA OPEX [51], the electricity cost was 0.06 $\$ \mathrm{kWh}^{-1}$ [54], labor costs were 50,833, 67,500, 84,167, and 100,833 \$ $\mathrm{y}^{-1}$ for $\mathrm{H}_{2}$ production capacities of $30,100,300$, and $700 \mathrm{~m}^{3} \mathrm{~h}^{-1}$, respectively [55], the membrane replacement cost was $20 \%$ that of the membrane module [56], the natural gas cost of $13.35 \$ \mathrm{MJ}^{-1}$ [57], the maintenance cost was $2 \%$ of FCI, and other costs were estimated as $1 \%$ of the FCI [58].

\subsection{Sensitivity analysis (SA)}

SA was used to investigate the effects of each parameter on the unit $\mathrm{H}_{2}$ production cost. The parameters considered in this study were the reactor, membrane module, compressor, PSA, supplement, reactant, PSA operating cost, sweep gas, electricity, labor, membrane replacement, natural gas, maintenance, and other costs. In the SA, the unit $\mathrm{H}_{2}$ production cost was determined by varying one parameter by $\pm 20 \%$ with the other parameters fixed.

\subsection{Carbon footprint analysis (CFA)}

To assess the environmental effect of MCH dehydrogenation in an MR compared to the a conventional PBR, CFA was conducted based on the results of the techno-economic analysis. The carbon footprint is classified according to the types of processes as follows; direct carbon emissions from controlled processes like chemical reactions or heater and indirect carbon emissions from uncontrolled processes such as electricity consumed in the compressor [59]. In this study, for both a $\mathrm{PBR}$ and an $\mathrm{MR}, \mathrm{CO}_{2}$ emissions from the dehydrogenation reactor and heater (direct carbon emission) and compressor (indirect carbon emission) were considered in CFA.

\section{Results and discussion}

\subsection{Itemized cost estimation}

Based on the results of process simulation, itemized cost estimation to determine a unit $\mathrm{H}_{2}$ production cost using $\mathrm{MCH}$ dehydrogenation in a PBR and an MR was carried out for $\mathrm{H}_{2}$ production scales of 30, 100, 300, and $700 \mathrm{~m}^{3} \mathrm{~h}^{-1}$ at $543 \mathrm{~K}$ and $\mathrm{H}_{2}$ permeance of $5 \times 10^{-5} \mathrm{~mol} \mathrm{~m}^{-2} \mathrm{~s}^{-1}$ $\mathrm{Pa}^{-1}$ to evaluate the economic feasibility of $\mathrm{MCH}$ dehydrogenation in the MR.

Table 1 shows the results of the itemized cost estimation for the unit $\mathrm{H}_{2}$ production cost for a PBR and an MR. Because the generated $\mathrm{H}_{2}$ is continuously separated and removed through the $\mathrm{H}_{2}$ separation membrane in an MR, the costs for additional $\mathrm{H}_{2}$ purification (PSA and PSA operating cost) are much lower for an MR than for a PBR. Instead, the costs for the membrane (membrane module, membrane replacement, and sweep gas) are additionally considered for an MR. The amount of reactant and natural gas utilized in the boiler are significantly lower in an MR compared to a PBR due to the improved $\mathrm{H}_{2}$ yield and lower heat requirement of the former leading to cheaper $\mathrm{H}_{2}$ production costs. For a $\mathrm{H}_{2}$ production capacity of $30 \mathrm{~m}^{3} \mathrm{~h}^{-1}$, unit $\mathrm{H}_{2}$ production costs were 11.76 and $9.37 \$ \mathrm{kgH}_{2}^{-1}$ for a PBR and an MR, respectively, representing a cost reduction of $20.3 \%$ for the MR compared to the PBR. Similarly, unit $\mathrm{H}_{2}$ production costs of 9.50 and $7.43 \mathrm{SgH}_{2}^{-1}$ were obtained representing a significantly larger cost reduction of $21.7 \%$ for an MR with a $\mathrm{H}_{2}$ production capacity of $100 \mathrm{~m}^{3} \mathrm{~h}^{-1}$. A similar trend was observed for the capacities of 300 and $700 \mathrm{~m}^{3} \mathrm{~h}^{-1}$, where the unit $\mathrm{H}_{2}$ production costs of 8.50 and $8.08 \$ \mathrm{kgH}_{2}^{-1}$ for a PBR and 6.58 and $6.23 \mathrm{kgH}_{2}^{-1}$ for an MR, respectively, and greater cost reductions of $22.6 \%$ and $22.9 \%$, respectively, were achieved with an MR. From these results, the economic feasibility of an MR in MCH dehydrogenation and the effect of scale-up on the economic competitiveness of an MR could be confirmed. When comparing the results from this study with previous reported data, the minimum unit $\mathrm{H}_{2}$ production cost of $6.23 \mathrm{\$} \mathrm{kgH}_{2}^{-1}$ in the MR at 700 $\mathrm{m}^{3} \mathrm{~h}^{-1}$ is still higher than ones by conventional methods such as steam 
Table 1

Itemized cost estimation of a packed-bed reactor (PBR) and a membrane reactor (MR) for $\mathrm{H}_{2}$ production capacities of $30,100,300$, and $700 \mathrm{~m}^{3} \mathrm{~h}^{-1}$.

\begin{tabular}{|c|c|c|c|c|}
\hline Items & $\begin{array}{l}\mathrm{PBR} / \$ \\
\mathrm{y}^{-1}\end{array}$ & $\begin{array}{l}\text { Unit } \mathrm{H}_{2} \\
\text { production cost/ } \\
\$ \mathrm{kgH}_{2}^{-1}\end{array}$ & $\mathrm{MR} / \$ \mathrm{y}^{-1}$ & $\begin{array}{l}\text { Unit } \mathrm{H}_{2} \\
\text { production cost/ } \\
\$ \mathrm{kgH}_{2}^{-1}\end{array}$ \\
\hline \multicolumn{5}{|l|}{$30 \mathrm{~m}^{3} \mathrm{~h}^{-1}$} \\
\hline 1. Capital Cost & 32,527 & 1.49 & 24,384 & 1.12 \\
\hline Reactor & 15,414 & 0.71 & 15,414 & 0.71 \\
\hline $\begin{array}{l}\text { Membrane } \\
\text { module }\end{array}$ & 0 & 0.00 & 96 & 0.00 \\
\hline Compressor & 2,008 & 0.09 & 887 & 0.04 \\
\hline PSA & 10,501 & 0.48 & 4,892 & 0.22 \\
\hline Supplement & 4,605 & 0.21 & 3,095 & 0.14 \\
\hline $\begin{array}{l}\text { 2. Operating } \\
\text { Cost }\end{array}$ & 224,137 & 10.27 & 180,041 & 8.25 \\
\hline Reactant & 145,676 & 6.68 & 109,864 & 5.03 \\
\hline PSA OPEX & 47 & 0.00 & 35 & 0.00 \\
\hline Sweep gas & 0 & 0.00 & 106 & 0.00 \\
\hline Electricity & 4,274 & 0.20 & 0 & 0.00 \\
\hline Labor & 50,833 & 2.33 & 50,833 & 2.33 \\
\hline \multicolumn{5}{|l|}{ Membrane } \\
\hline Natural gas & 14,323 & 0.66 & 13,145 & 0.60 \\
\hline Maintenance & 5,990 & 0.27 & 4,025 & 0.18 \\
\hline Other cost & 2,995 & 0.14 & 2,013 & 0.09 \\
\hline 3. Total Cost & 256,664 & 11.76 & 204,425 & 9.37 \\
\hline \multicolumn{5}{|l|}{$100 \mathrm{~m}^{3} \mathrm{~h}^{-1}$} \\
\hline 1. Capital Cost & 66,985 & 0.92 & 50,101 & 0.69 \\
\hline Reactor & 31,743 & 0.44 & 31,743 & 0.44 \\
\hline $\begin{array}{l}\text { Membrane } \\
\text { module }\end{array}$ & 0 & 0.00 & 96 & 0.00 \\
\hline Compressor & 4,134 & 0.06 & 1,827 & 0.03 \\
\hline PSA & 21,625 & 0.30 & 10,075 & 0.14 \\
\hline Supplement & 9,482 & 0.13 & 6,360 & 0.09 \\
\hline $\begin{array}{l}\text { 2. Operating } \\
\text { Cost }\end{array}$ & 623,761 & 8.58 & 490,184 & 6.74 \\
\hline Reactant & 485,586 & 6.68 & 366,215 & 5.03 \\
\hline PSA OPEX & 156 & 0.00 & 118 & 0.00 \\
\hline Sweep gas & 0 & 0.00 & 106 & 0.00 \\
\hline Electricity & 4,274 & 0.06 & 0 & 0.00 \\
\hline Labor & 67,500 & 0.93 & 67,500 & 0.93 \\
\hline \multicolumn{5}{|l|}{ Membrane } \\
\hline Natural gas & 47,742 & 0.66 & 43,817 & 0.60 \\
\hline Maintenance & 12,335 & 0.17 & 8,273 & 0.11 \\
\hline Other cost & 6,167 & 0.08 & 4,137 & 0.06 \\
\hline 3. Total Cost & 690,746 & 9.50 & 540,285 & 7.43 \\
\hline \multicolumn{5}{|l|}{$300 \mathrm{~m}^{3} \mathrm{~h}^{-1}$} \\
\hline 1. Capital Cost & 129,494 & 0.59 & 96,754 & 0.44 \\
\hline Reactor & 61,365 & 0.28 & 61,365 & 0.28 \\
\hline $\begin{array}{l}\text { Membrane } \\
\text { module }\end{array}$ & 0 & 0.00 & 96 & 0.00 \\
\hline Compressor & 7,992 & 0.04 & 3,531 & 0.02 \\
\hline PSA & 41,805 & 0.19 & 19,477 & 0.09 \\
\hline Supplement & 18,331 & 0.08 & 12,285 & 0.06 \\
\hline $\begin{array}{l}\text { 2. Operating } \\
\text { Cost }\end{array}$ & $1,724,663$ & 7.90 & $1,338,708$ & 6.13 \\
\hline Reactant & $1,456,759$ & 6.68 & $1,098,644$ & 5.03 \\
\hline PSA OPEX & 469 & 0.00 & 353 & 0.00 \\
\hline Sweep gas & 0 & 0.00 & 106 & 0.00 \\
\hline Electricity & 4,274 & 0.02 & 0 & 0.00 \\
\hline Labor & 84,167 & 0.39 & 84,167 & 0.39 \\
\hline \multicolumn{5}{|l|}{ Membrane } \\
\hline Natural gas & 143,226 & 0.66 & 131,450 & 0.60 \\
\hline Maintenance & 23,845 & 0.11 & 15,980 & 0.07 \\
\hline Other cost & 11,923 & 0.05 & 7,990 & 0.04 \\
\hline 3. Total Cost & $1,854,157$ & 8.50 & $1,435,463$ & 6.58 \\
\hline \multicolumn{5}{|l|}{$700 \mathrm{~m}^{3} \mathrm{~h}^{-1}$} \\
\hline 1. Capital Cost & 215,295 & 0.42 & 160,791 & 0.32 \\
\hline Reactor & 102,025 & 0.20 & 102,025 & 0.20 \\
\hline $\begin{array}{l}\text { Membrane } \\
\text { module }\end{array}$ & 0 & 0.00 & 96 & 0.00 \\
\hline Compressor & 13,288 & 0.03 & 5,871 & 0.01 \\
\hline PSA & 69,504 & 0.14 & 32,383 & 0.06 \\
\hline
\end{tabular}

Table 1 (continued)

\begin{tabular}{lllll}
\hline Items & $\begin{array}{l}\mathrm{PBR} / \$ \\
\mathrm{y}^{-1}\end{array}$ & $\begin{array}{l}\text { Unit } \mathrm{H}_{2} \\
\text { production cost/ } \\
\$ \mathrm{kgH}_{2}^{-1}\end{array}$ & $\mathrm{MR} / \$ \mathrm{y}^{-1}$ & $\begin{array}{l}\text { Unit } \mathrm{H}_{2} \\
\text { production cost/ } \\
\$ \mathrm{kgH}_{2}^{-1}\end{array}$ \\
\hline $\begin{array}{l}\text { Supplement } \\
\text { 2. Operating }\end{array}$ & 30,478 & 0.06 & 20,417 & 0.04 \\
$\quad$ Cost & $3,898,968$ & 7.66 & $3,011,837$ & 5.92 \\
Reactant & $3,399,105$ & 6.68 & & \\
PSA OPEX & 1,094 & 0.00 & $2,563,502$ & 5.03 \\
Sweep gas & 0 & 0.00 & 824 & 0.00 \\
Electricity & 4,274 & 0.01 & 106 & 0.00 \\
Labor & 100,833 & 0.20 & 0 & 0.00 \\
Membrane & & & 100,833 & 0.20 \\
replacement & 0 & 0.00 & 19 & 0.00 \\
Natural gas & 334,195 & 0.66 & 306,716 & 0.60 \\
Maintenance & 39,645 & 0.08 & 26,558 & 0.05 \\
Other cost & 19,823 & 0.04 & 13,279 & 0.03 \\
3. Total Cost & $4,114,264$ & 8.08 & $3,172,628$ & 6.23 \\
\hline
\end{tabular}

methane reforming $\left(2.27 \$ \mathrm{kgH}_{2}^{-1}\right)$ and methane pyrolysis (1.59-1.70 \$ $\mathrm{kgH}_{2}^{-1}$ ), but economically competitive with other developing technologies such as solar photovoltaic electrolysis (5.78-23.27 $\$ \mathrm{kgH}_{2}^{-1}$ ) and nuclear electrolysis (4.15-7.00 \$ kgH ${ }_{2}^{-1}$ ) [60].

Fig. 4. compares the economic parameter component ratio for a PBR and an MR, indicating a very high operating cost ratio for both systems. This was especially evident when the $\mathrm{H}_{2}$ production capacity of both systems was increased, indicating a high operating cost ratio of $95 \%$ for both a PBR and an MR. With increasing $\mathrm{H}_{2}$ production capacity, the main economic parameter influencing the economic cost changed from labor to natural gas, where the labor ratios were of $20 \%$ and $2 \%$ for a PBR and $25 \%$ and $3 \%$ for an MR in $\mathrm{H}_{2}$ production capacities of 30 and $700 \mathrm{~m}^{3} \mathrm{~h}^{-1}$, respectively. The natural gas ratios were obtained as $6 \%$ and $8 \%$ for a $\mathrm{PBR}$ and $6 \%$ and $10 \%$ for an $\mathrm{MR}$ for $\mathrm{H}_{2}$ production capacities of 30 and $700 \mathrm{~m}^{3} \mathrm{~h}^{-1}$, respectively. The reactant cost was highly influential economic parameter for both systems and capacities. Based on these results, the important economic parameters for MCH dehydrogenation were determined and the economic feasibility of an MR was demonstrated, with reduction of the unit $\mathrm{H}_{2}$ production cost.

\subsection{Sensitivity analysis (SA)}

To investigate effects of each economic parameter on the unit $\mathrm{H}_{2}$ production cost, SA was conducted by varying each factor in the range of $\pm 20 \%$ with the other parameters fixed.

Figs. 5 and 6 show the results of the SA, where the key parameters are marked with an asterisk $(*)$; the figures also show the ranges of the unit $\mathrm{H}_{2}$ production cost variation. For all $\mathrm{H}_{2}$ production capacities of 30,100 , 300 , and $700 \mathrm{~m}^{3} \mathrm{~h}^{-1}$, the reactant cost was identified as the most impactful economic parameter influencing the unit $\mathrm{H}_{2}$ production cost, where the variation in the unit $\mathrm{H}_{2}$ production cost was $11.35 \%, 14.05 \%$, $15.72 \%$, and $16.49 \%$ for a PBR and $10.77 \%, 13.54 \%, 15.29 \%$, and $16.17 \%$ for an MR at the respective production capacities. The next most influential economic parameters differed depending on the $\mathrm{H}_{2}$ production capacity. For a PBR, labor was found to be the next most influential economic parameter, where the variation in the unit $\mathrm{H}_{2}$ production cost was $3.96 \%$ and $1.96 \%$ for $\mathrm{H}_{2}$ production capacities of 30 and $100 \mathrm{~m}^{3}$ $\mathrm{h}^{-1}$, respectively. However, for the capacities of 300 and $700 \mathrm{~m}^{3} \mathrm{~h}^{-1}$, natural gas was identified as next most influential parameter, where the variation in the unit $\mathrm{H}_{2}$ production cost was of $1.55 \%$ and $1.63 \%$, respectively. A similar trend was also observed for the MR, labor was identified as the next most influential economic parameter, and the variation in the unit $\mathrm{H}_{2}$ production cost was $4.99 \%$ and $2.50 \%$, respectively, for $\mathrm{H}_{2}$ production capacities of 30 and $100 \mathrm{~m}^{3} \mathrm{~h}^{-1}$. Similar to the PBR, the next most influential economic parameter changed from labor to natural gas, with variations of $1.82 \%$ and $1.93 \%$ when the capacity was increased from 300 to $700 \mathrm{~m}^{3} \mathrm{~h}^{-1}$. In short, reactant cost, labor, and natural gas were identified as the key economic parameters through SA 

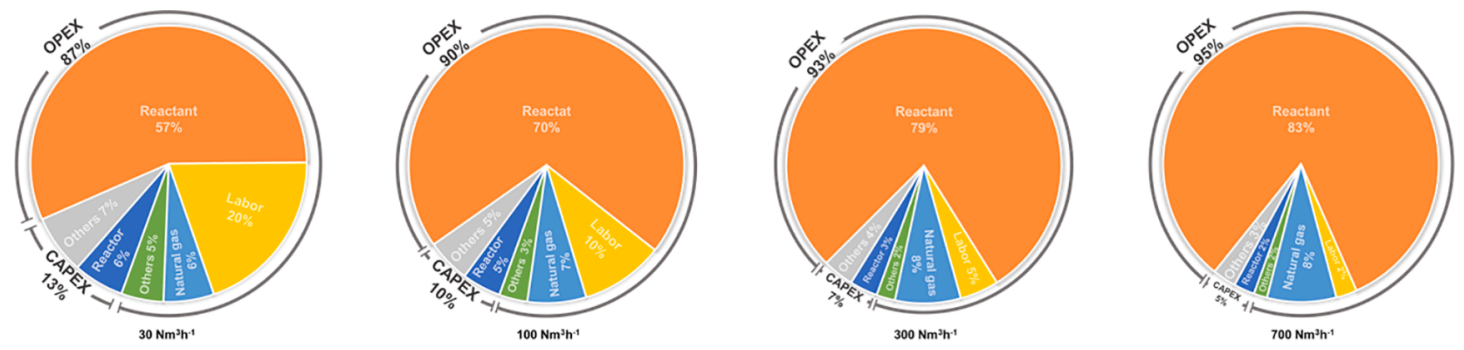

(a) PBR
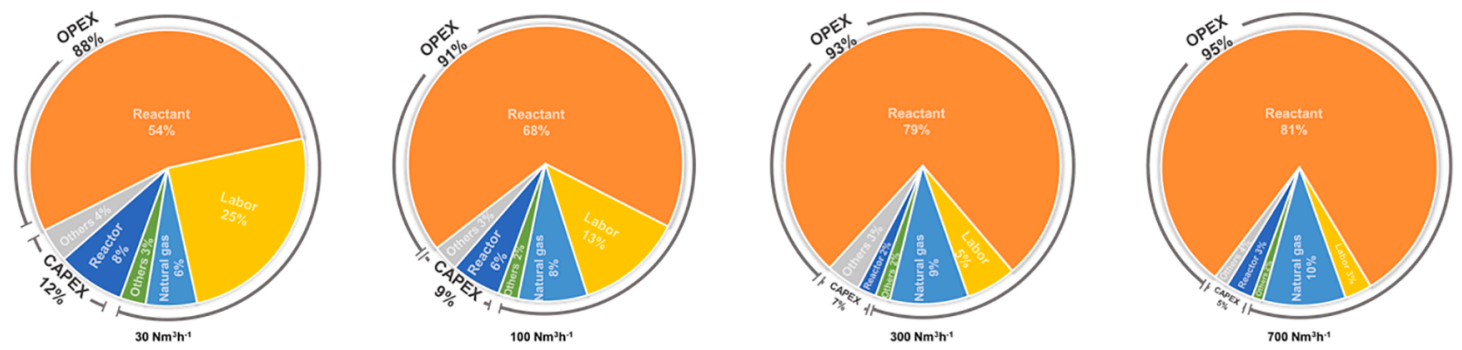

(b) MR

Fig. 4. Pie diagram of a unit $\mathrm{H}_{2}$ production cost for (a) a packed-bed reactor (PBR) and (b) a membrane reactor (MR) with $\mathrm{H}_{2}$ production capacities of 30, 100, 300, and $700 \mathrm{~m}^{3} \mathrm{~h}^{-1}$.
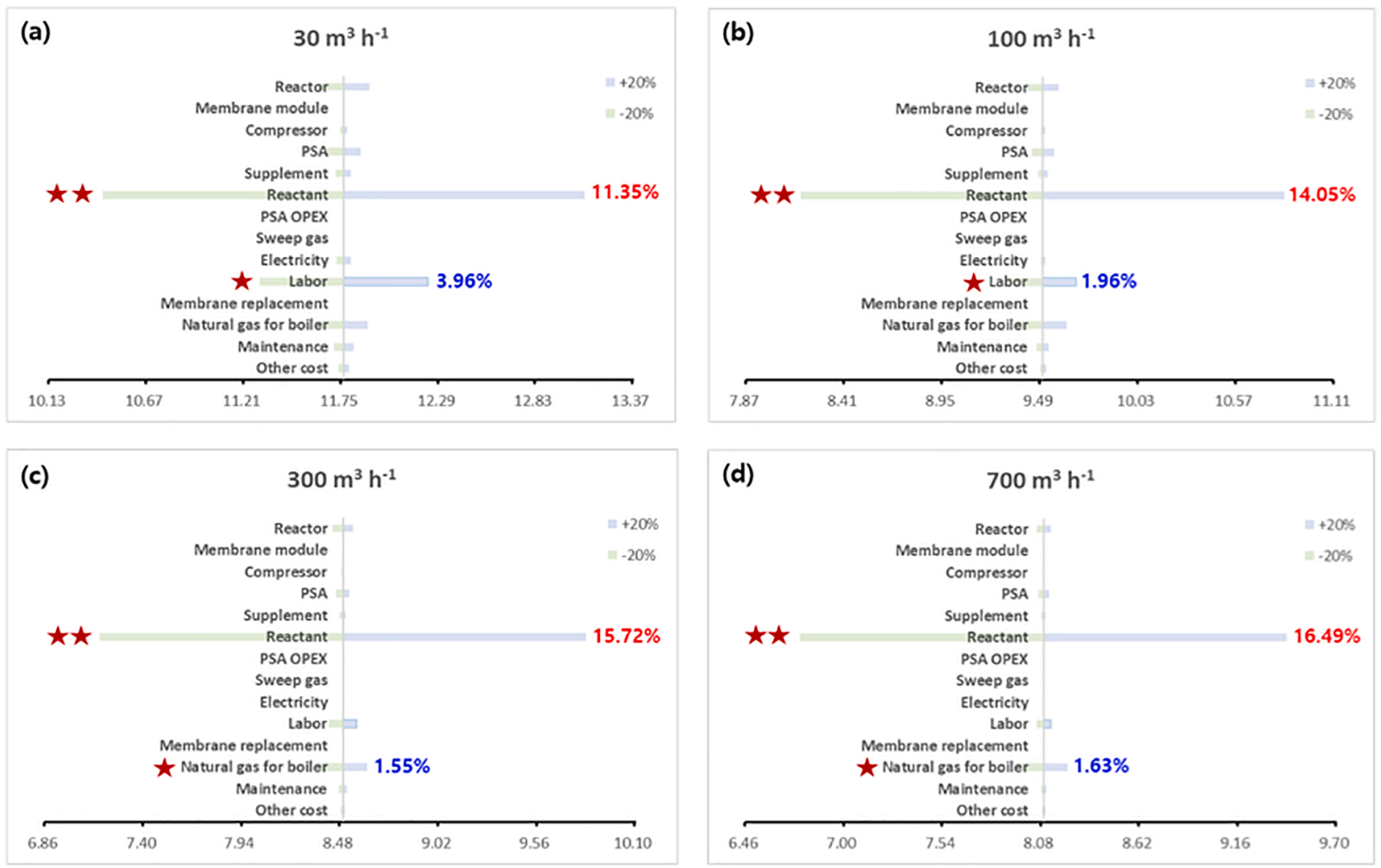

Fig. 5. Sensitivity analysis (SA) results of a packed-bed reactor (PBR) for $\mathrm{H}_{2}$ production capacities of (a) 30, (b) 100, (c) 300 , and (d) $700 \mathrm{~m}^{3} \mathrm{~h}^{-1}$.

and the trend for each parameter in $\mathrm{MCH}$ dehydrogenation with variation of the $\mathrm{H}_{2}$ production capacity was quantified.

\subsection{Scenario analysis}

3.3.1. $H_{2}$ production capacity

Because of the continuous growth in the demand for $\mathrm{H}_{2}$ along with various policies and technical improvements, small-scale $\mathrm{H}_{2}$ production should be implemented for distributed application. Currently, the $\mathrm{H}_{2}$ 

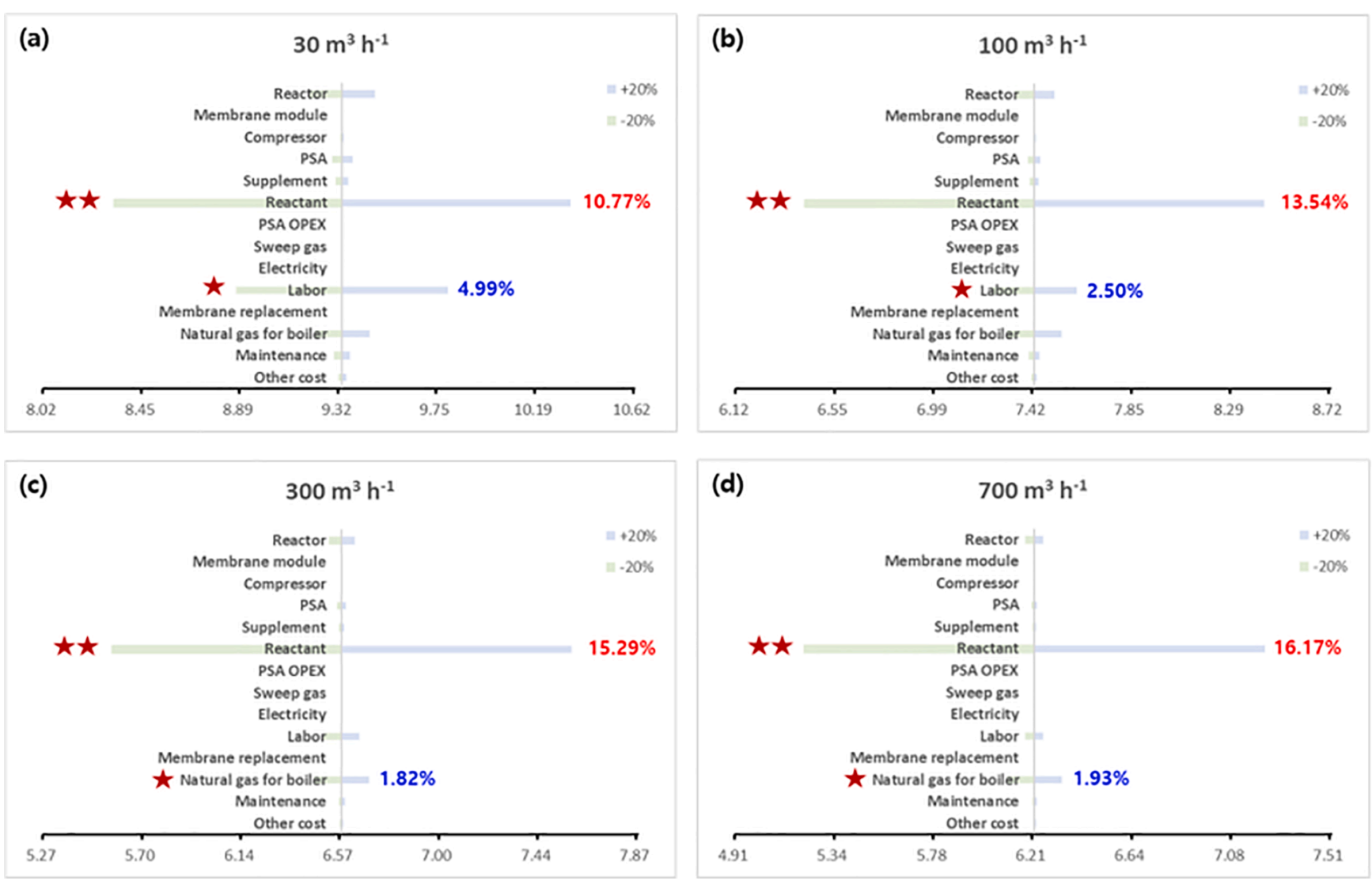

Fig. 6. Sensitivity analysis (SA) results of a membrane reactor (MR) for $\mathrm{H}_{2}$ production capacities of (a) 30 , (b) 100 , (c) 300 , and (d) $700 \mathrm{~m}^{3} \mathrm{~h}^{-1}$.

production capacity of on-site $\mathrm{H}_{2}$ refueling stations is typically less than $187 \mathrm{~m}^{3} \mathrm{~h}^{-1}$, with an average value of $47 \mathrm{~m}^{3} \mathrm{~h}^{-1}$ [61]. However, to accomplish a successful $\mathrm{H}_{2}$ society and replace conventional fossil fuel with $\mathrm{H}_{2}$ energy, economic feasibility study involving a more diverse $\mathrm{H}_{2}$ production capacity is essential. Scenario analysis was used to investigate the variation of the $\mathrm{H}_{2}$ production cost based on the $\mathrm{H}_{2}$ production scale. The investigated range of the $\mathrm{H}_{2}$ production scale was from 30 to $700 \mathrm{~m}^{3} \mathrm{~h}^{-1}$ and the unit $\mathrm{H}_{2}$ production cost for each capacity was estimated by employing the conventional $\mathrm{PBR}$ and $\mathrm{H}_{2}$ permeance values of $5 \times 10^{-7}, 5 \times 10^{-6}$, and $5 \times 10^{-5} \mathrm{~mol} \mathrm{~m}^{-2} \mathrm{~s}^{-1} \mathrm{~Pa}^{-1}$ at three different temperature of 483,513 , and $543 \mathrm{~K}$. As confirmed earlier, use of an MR can enable reduction of the unit $\mathrm{H}_{2}$ production cost compared that for a PBR and the cost reduction effect becomes more impactful as the $\mathrm{H}_{2}$ permeance of the membrane increases.

Fig. 7 shows the results of the scenario analysis at temperature of 483,513 , and $543 \mathrm{~K}$. At $483 \mathrm{~K}$, the unit $\mathrm{H}_{2}$ production cost and extent of cost reduction decreased as the $\mathrm{H}_{2}$ production scale increased. For a PBR, the possible $\mathrm{H}_{2}$ production cost range was from 47.92 to 43.93 \$
$\mathrm{kgH}_{2}^{-1}$, with respective ranges of 47.31 to $43.70 \$ \mathrm{kgH}_{2}^{-1}, 46.24$ to 42.72 $\$ \mathrm{kgH}_{2}^{-1}$, and 36.62 to $33.14 \$ \mathrm{kgH}_{2}^{-1}$ for the $\mathrm{H}_{2}$ permeances of $5 \times 10^{-7}$, $5 \times 10^{-6}$, and $5 \times 10^{-5} \mathrm{~mol} \mathrm{~m}^{-2} \mathrm{~s}^{-1} \mathrm{~Pa}^{-1}$. At the maximum investigated $\mathrm{H}_{2}$ production capacity of $700 \mathrm{~m}^{3} \mathrm{~h}^{-1}$, the unit $\mathrm{H}_{2}$ production cost for a PBR of $43.93 \$ \mathrm{kgH}_{2}^{-1}$ was reduced to $33.14 \$ \mathrm{kgH}_{2}^{-1}$ for an $\mathrm{MR}$, where cost reduction of $24.6 \%$ is larger than that (23.6\%) achieved with a $\mathrm{H}_{2}$ production capacity of $30 \mathrm{~m}^{3} \mathrm{~h}^{-1}$. Similar trends were observed for temperatures of 513 and $543 \mathrm{~K}$, where the unit $\mathrm{H}_{2}$ production cost and extent of cost reduction declined as the $\mathrm{H}_{2}$ production capacity increased. For temperatures of 513 and $543 \mathrm{~K}$, ranges of 20.78 to $17.03 \$$ $\mathrm{kgH}_{2}^{-1}$ and 11.76 to $8.09 \$ \mathrm{kgH}_{2}^{-1}$ for a PBR, 20.30 to $16.87 \$ \mathrm{kgH}_{2}^{-1}$ and 11.30 to $8.00 \$ \mathrm{kgH}_{2}^{-1}, 19.71$ to $16.32 \$ \mathrm{kgH}_{2}^{-1}$ and 11.12 to $7.84 \$$ $\mathrm{kgH}_{2}^{-1}, 14.00$ to $10.69 \$ \mathrm{kgH}_{2}^{-1}$ and 9.37 to $6.23 \$ \mathrm{kgH}_{2}^{-1}$ for permeance of $5 \times 10^{-7}, 5 \times 10^{-6}$, and $5 \times 10^{-5} \mathrm{~mol} \mathrm{~m}^{-2} \mathrm{~s}^{-1} \mathrm{~Pa}^{-1}$, respectively, were obtained. Similar to the case of $483 \mathrm{~K}$, the cost reductions for a PBR versus an MR increased from $32.6 \%$ to $36.6 \%$ at $513 \mathrm{~K}$ and from $20.3 \%$ to $22.9 \%$ at $543 \mathrm{~K}$.

From the comprehensive perspective, the unit $\mathrm{H}_{2}$ production cost at
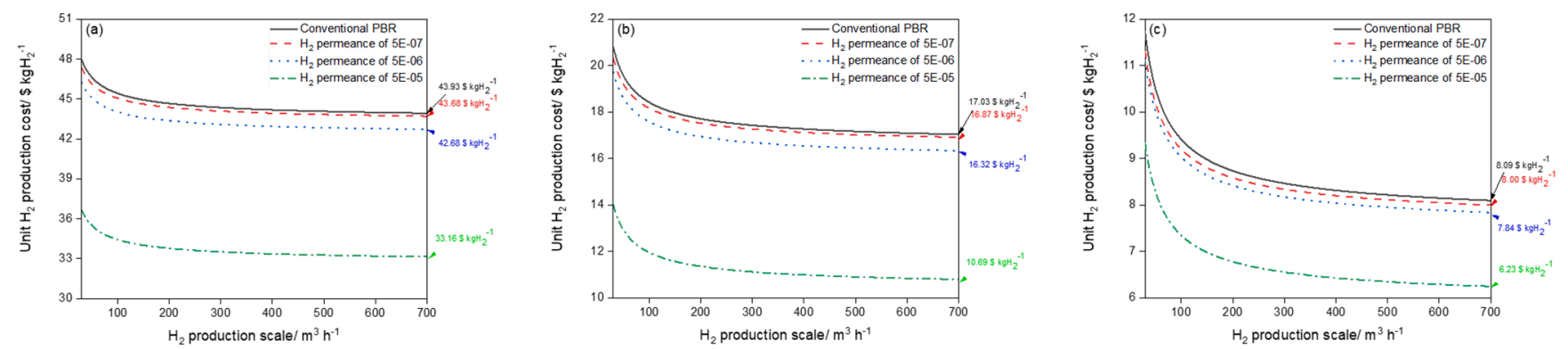

Fig. 7. Scenario analysis on a unit $\mathrm{H}_{2}$ production cost between a packed-bed reactor (PBR) and a membrane reactor (MR) for $\mathrm{H}_{2}$ production capacities of 30 to 700 $\mathrm{m}^{3} \mathrm{~h}^{-1}$ with different permeance of $5 \times 10^{-7}, 5 \times 10^{-6}$, and $5 \times 10^{-5} \mathrm{~mol} \mathrm{~m}^{-2} \mathrm{~s}^{-1} \mathrm{~Pa}^{-1}$ at (a) 483, (b) 513, and (c) $543 \mathrm{~K}$. 
the permeance of $5 \times 10^{-5} \mathrm{~mol} \mathrm{~m}^{-2} \mathrm{~s}^{-1} \mathrm{~Pa}^{-1}$ was dramatically lowered compared to the other three cases, confirming the economic feasibility of an MR and the need for technical improvement. In addition, as the temperature increased, the decline in the $\mathrm{H}_{2}$ production cost became more pronounced, suggesting the probability for further reduction of the unit $\mathrm{H}_{2}$ production cost in an MR.

In short, the overall trend of the unit $\mathrm{H}_{2}$ production cost depending on the $\mathrm{H}_{2}$ production capacity was investigated for different temperatures and permeances. The results clearly show that technical advances and operation at proper reaction temperature can lead to economic competitiveness of $\mathrm{H}_{2}$ production using MCH dehydrogenation in an MR at the on-site scale, compared to the a PBR system.

\subsubsection{Temperature}

As shown in Fig. 2, the MCH conversion can be improved by increasing the operating temperature because of the endothermic nature of MCH dehydrogenation. Enhancing MCH conversion can influence the unit $\mathrm{H}_{2}$ production cost by decreasing the amount of feedstock. Based on this close relationship between the reaction temperature and $\mathrm{H}_{2}$ production cost, scenario analysis in terms of the temperature was carried out to determine the overall trend of effect of temperature on the unit $\mathrm{H}_{2}$ production cost.

Fig. 8 shows the results of scenario analysis when the temperature was varied in the range of 483 to $543 \mathrm{~K}$ for a $\mathrm{H}_{2}$ production capacity of $30 \mathrm{~m}^{3} \mathrm{~h}^{-1}$. As expected, the $\mathrm{H}_{2}$ production cost dramatically decreased as the temperature increased in all cases emphasizing the importance of proper reaction temperature and showing cost reductions of $75.2 \%$, $76.7 \%, 76.1 \%$, and $74.4 \%$ for a PBR and $\mathrm{H}_{2}$ permeance of $5 \times 10^{-7}, 5 \times$ $10^{-6}$, and $5 \times 10^{-5} \mathrm{~mol} \mathrm{~m}^{-2} \mathrm{~s}^{-1} \mathrm{~Pa}^{-1}$ at temperatures between 483 and $543 \mathrm{~K}$. The $\mathrm{H}_{2}$ production costs differed minimally for a PBR, $\mathrm{H}_{2}$ permeances of $5 \times 10^{-7}$ and $5 \times 10^{-6} \mathrm{~mol} \mathrm{~m}^{-2} \mathrm{~s}^{-1} \mathrm{~Pa}^{-1}$, where the $\mathrm{H}_{2}$ production cost ranged from 47.92 to $11.76 \$ \mathrm{kgH}_{2}^{-1}, 47.31$ to $11.30 \$$ $\mathrm{kgH}_{2}^{-1}$, and 46.24 to $9.95 \$ \mathrm{kgH}_{2}^{-1}$, respectively. However, in case of a $\mathrm{H}_{2}$ permeance of $5 \times 10^{-5} \mathrm{~mol} \mathrm{~m}^{-2} \mathrm{~s}^{-1} \mathrm{~Pa}^{-1}$, significantly decreased $\mathrm{H}_{2}$ production costs were obtained in a range of 36.62 to $9.37 \$ \mathrm{kgH}_{2}^{-1}$. Furthermore, the rate of cost reduction flatlined beyond $533 \mathrm{~K}$ when the permeance was $5 \times 10^{-5} \mathrm{~mol} \mathrm{~m}^{-2} \mathrm{~s}^{-1} \mathrm{~Pa}^{-1}$; however, the $\mathrm{H}_{2}$ production costs are likely to continue to decline at even higher reaction temperatures, suggesting technical improvement of an MR and thus a lower heat requirement.

In short, scenario analysis focusing on the temperature indicated significant effects of both temperature and $\mathrm{H}_{2}$ permeance on the unit $\mathrm{H}_{2}$ production cost.

\subsection{3. $\mathrm{H}_{2}$ permeance}

Because the novelty of an MR involves the use of a $\mathrm{H}_{2}$ permeable membrane, technical improvement of the membrane may enhance the economic feasibility of MCH dehydrogenation in an MR. According to Le Chatelier's principle, high $\mathrm{H}_{2}$ permeance can enable increased $\mathrm{H}_{2}$ production similar to the effect of temperature on $\mathrm{H}_{2}$ production, thereby reducing the $\mathrm{H}_{2}$ production cost. Based on these facts, scenario analysis focusing on the $\mathrm{H}_{2}$ permeance at different temperatures (483, 513, and $543 \mathrm{~K}$ ) was conducted to investigate the impact on the $\mathrm{H}_{2}$ production cost.

As shown in Fig. 9, the unit $\mathrm{H}_{2}$ production costs declined as the permeance increased in the range of $5 \times 10^{-7}$ to $5 \times 10^{-4} \mathrm{~mol} \mathrm{~m}^{-2} \mathrm{~s}^{-1}$ $\mathrm{Pa}^{-1}$.

At the temperature of $483 \mathrm{~K}$, the unit $\mathrm{H}_{2}$ production cost ranged from 47.31 to $45.14 \$ \mathrm{kgH}_{2}^{-1}$ for permeances of up to $1 \times 10^{-5} \mathrm{~mol} \mathrm{~m}^{-2} \mathrm{~s}^{-1}$ $\mathrm{Pa}^{-1}$, where the rate of cost reduction was low. However, at higher permeance, a very high rate of cost reduction was achieved and the decline continued up to the end point of $1 \times 10^{-4} \mathrm{~mol} \mathrm{~m}^{-2} \mathrm{~s}^{-1} \mathrm{~Pa}^{-1}$, with resulting $\mathrm{H}_{2}$ production costs of 45.14 to $18.46 \$ \mathrm{kgH}_{2}^{-1}$. At $513 \mathrm{~K}$, the cost reduction followed a similar trend, where rate of cost reduction was lower up to a permeance of $1 \times 10^{-5} \mathrm{~mol} \mathrm{~m}^{-2} \mathrm{~s}^{-1} \mathrm{~Pa}^{-1}$, compared to the case at $483 \mathrm{~K}$, with $\mathrm{H}_{2}$ production costs of 20.30 to $19.03 \$ \mathrm{kgH}_{2}^{-1}$. Similar to the case at $483 \mathrm{~K}$, from a certain turning point, i.e., $1 \times 10^{-5}$ mol m $\mathrm{m}^{-2} \mathrm{~s}^{-1} \mathrm{~Pa}^{-1}$, a relatively higher, but much lower rate of cost reduction compared to a case at $483 \mathrm{~K}$, was obtained up to a permeance of $1 \times 10^{-4} \mathrm{~mol} \mathrm{~m}^{-2} \mathrm{~s}^{-1} \mathrm{~Pa}^{-1}$ with unit $\mathrm{H}_{2}$ production costs of 19.03 to $10.56 \$ \mathrm{kgH}_{2}^{-1}$. However, from that limiting point, the unit $\mathrm{H}_{2}$ production costs flatlined, with a very narrow cost range of 10.56 to 10.54 \$ $\mathrm{kgH}_{2}^{-1}$. The lowest rate of reduction of the unit $\mathrm{H}_{2}$ production cost (11.24 to $9.07 \$ \mathrm{kgH}_{2}^{-1}$ ) was obtained at $543 \mathrm{~K}$, where the degree of cost reduction was $19.6 \%$ between the end points of $5 \times 10^{-7}$ and $5 \times 10^{-4}$ $\mathrm{mol} \mathrm{m} \mathrm{m}^{-2} \mathrm{~s}^{-1} \mathrm{~Pa}^{-1}$ compared to $60.9 \%$ and $48.5 \%$ for 483 and $513 \mathrm{~K}$.

These results show that the $\mathrm{H}_{2}$ permeance affects the rate of reduction of the unit $\mathrm{H}_{2}$ production cost, and the latter decreased as the

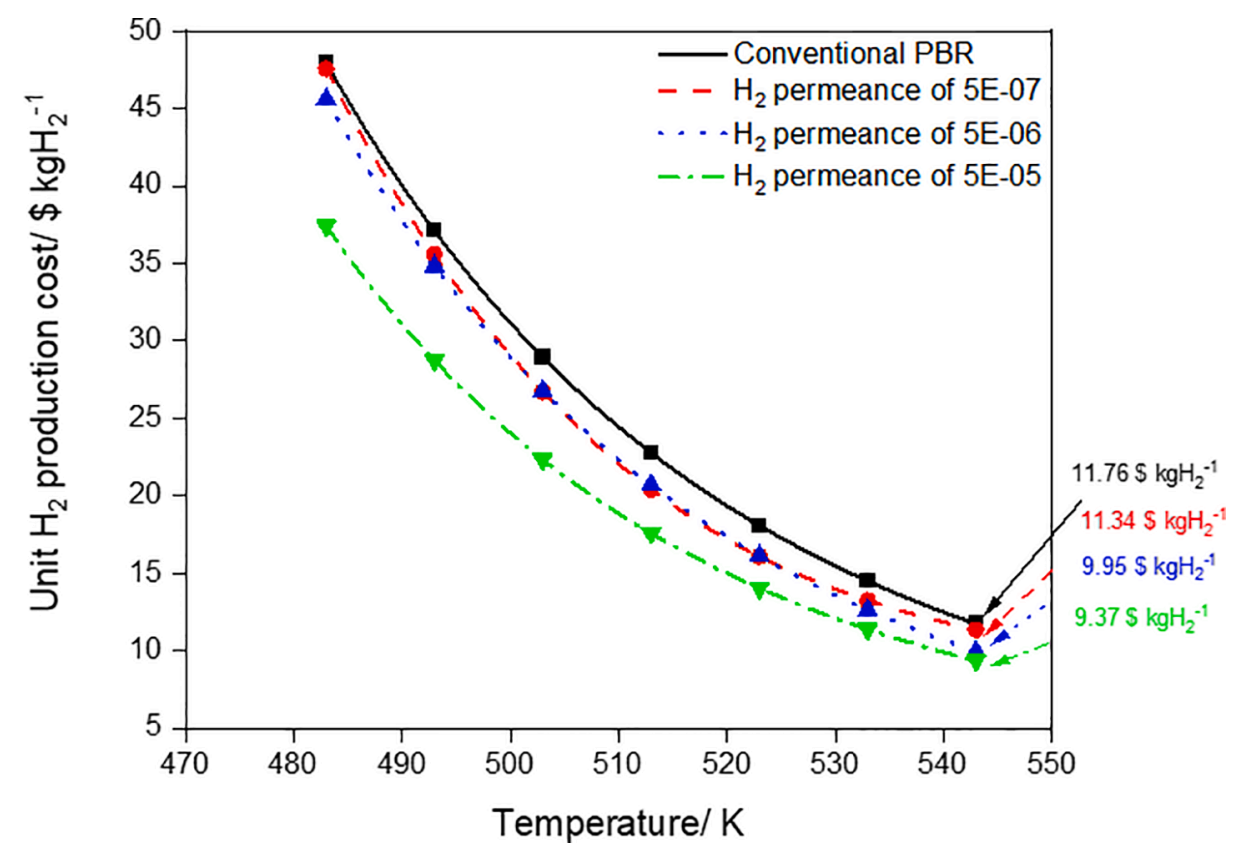

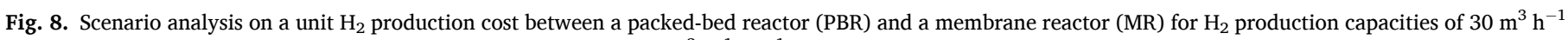
with different permeance of $5 \times 10^{-7}, 5 \times 10^{-6}$, and $5 \times 10^{-5} \mathrm{~mol} \mathrm{~m}^{-2} \mathrm{~s}^{-1} \mathrm{~Pa}^{-1}$ and temperature of 483 to $543 \mathrm{~K}$. 


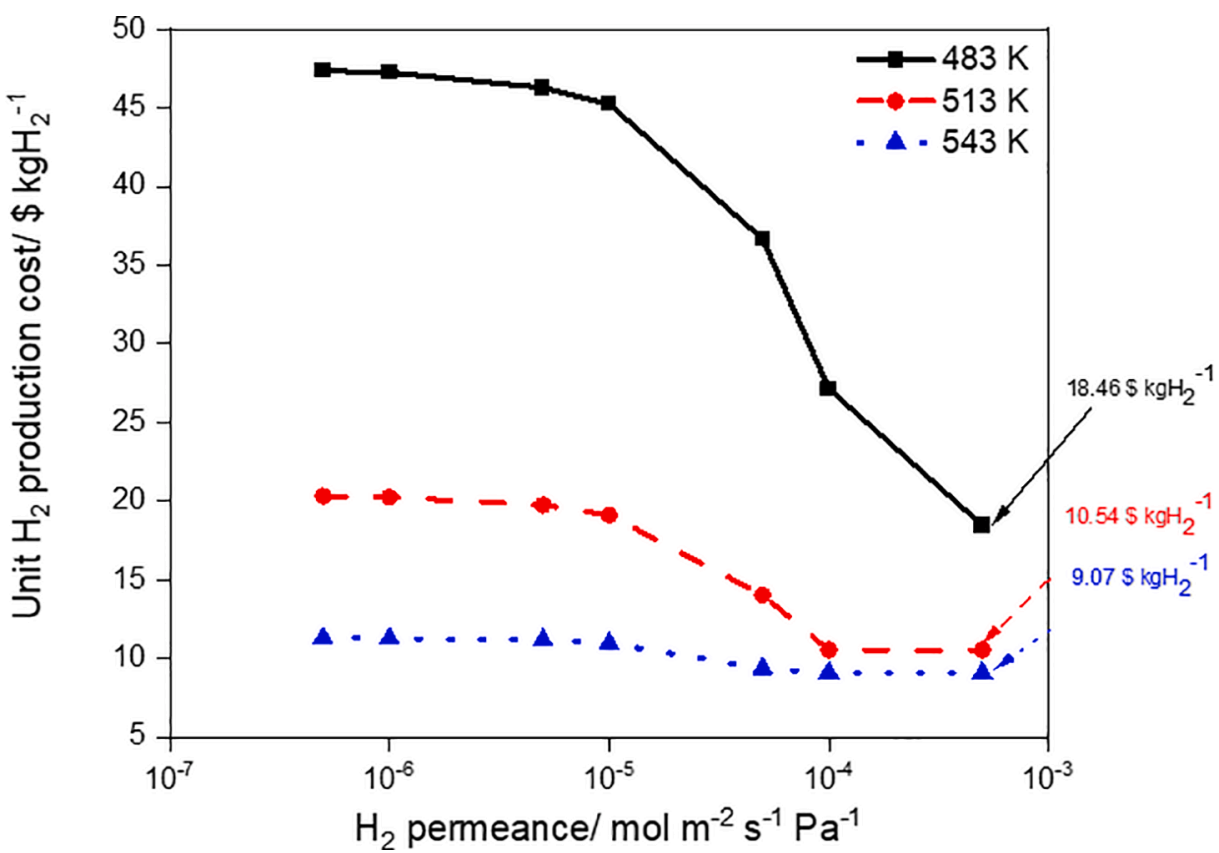

Fig. 9. Unit $\mathrm{H}_{2}$ production cost of a membrane reactor (MR) for $\mathrm{H}_{2}$ production capacity of $30 \mathrm{~m}^{3} \mathrm{~h}^{-1}$ with permeance of $5 \times 10^{-7}$ to $5 \times 10^{-4} \mathrm{~mol} \mathrm{~m}^{-2} \mathrm{~s}^{-1} \mathrm{~Pa}^{-1}$ and temperature of 483,513 , and $543 \mathrm{~K}$.

(a) $30 \mathrm{~m}^{3} \mathrm{~h}^{-1}$

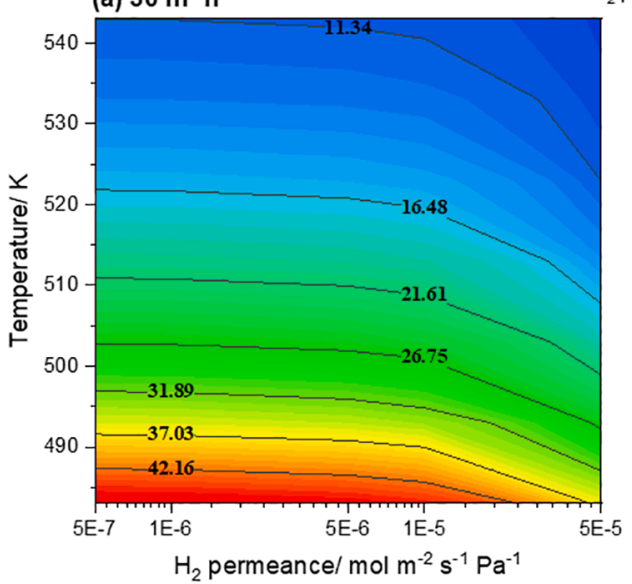

(c) $300 \mathrm{~m}^{3} \mathrm{~h}^{-1}$

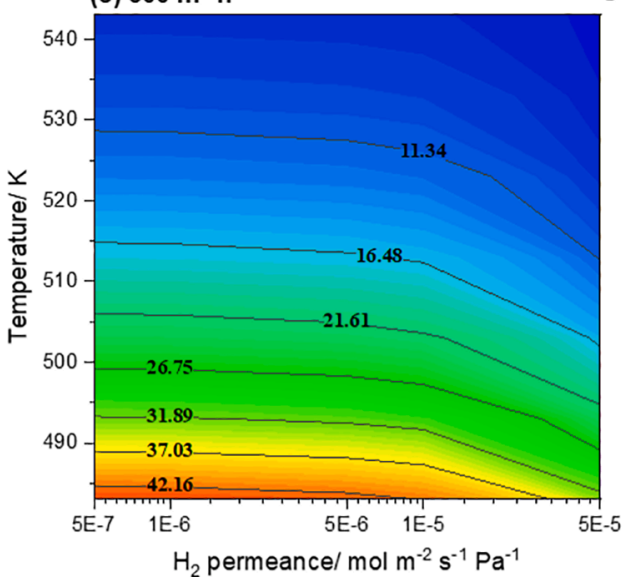

(b) $100 \mathrm{~m}^{3} \mathrm{~h}^{-1}$
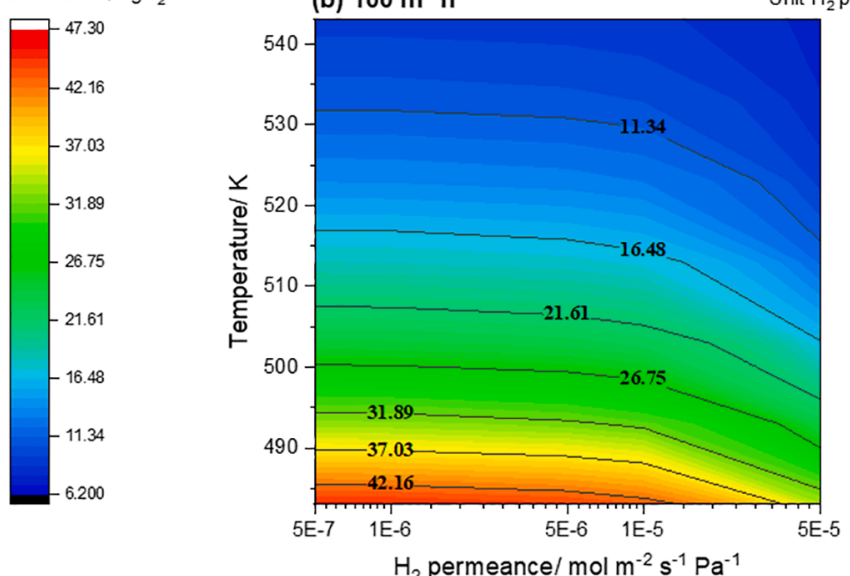

(d) $700 \mathrm{~m}^{3} \mathrm{~h}^{-1}$

Unit $\mathrm{H}_{2}$ production cost/ $\mathrm{S} \mathrm{kgH}_{2}^{-1}$

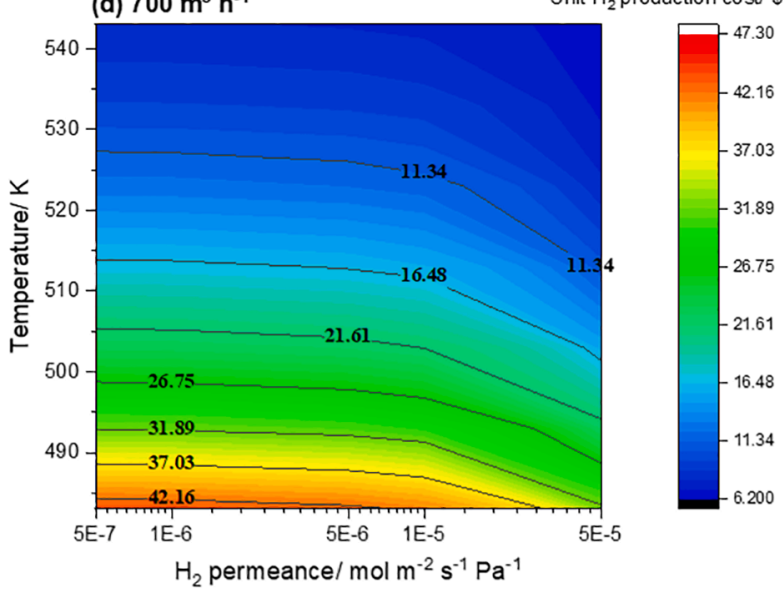

Fig. 10. Comprehensive scenario analysis on a unit $\mathrm{H}_{2}$ production cost of a membrane reactor (MR) for $\mathrm{H}_{2}$ production capacity of (a) 30 , (b) 100 , (c) 300 , and (d) $700 \mathrm{~m}^{3} \mathrm{~h}^{-1}$ with temperature of 483 to $543 \mathrm{~K}$ and permeance of $5 \times 10^{-7}$ to $5 \times 10^{-5} \mathrm{~mol} \mathrm{~m}^{-2} \mathrm{~s}^{-1} \mathrm{~Pa}^{-1}$. 
temperature increased.

\subsubsection{Comprehensive study}

Scenario analyses focusing on the effects of the $\mathrm{H}_{2}$ production capacity, temperature, and $\mathrm{H}_{2}$ permeance on the unit $\mathrm{H}_{2}$ production cost were performed. To investigate these parameters more extensively, comprehensive scenario study expressed as color map and contour plot was conducted with overall unit $\mathrm{H}_{2}$ production costs depending on temperature and $\mathrm{H}_{2}$ permeance at various $\mathrm{H}_{2}$ production capacities.

Fig. 10 shows the unit $\mathrm{H}_{2}$ production cost distributions at $\mathrm{H}_{2}$ production capacities of (a) 30, (b) 100 , (c) 300 , and (d) $700 \mathrm{~m}^{3} \mathrm{~h}^{-1}$, where the red to blue areas correspond to 47.3 to $6.2 \mathrm{\$} \mathrm{kgH}_{2}^{-1}$; the contour plot indicates certain unit $\mathrm{H}_{2}$ production costs of 42.16, 37.03, 31.89, 26.75, $21.61,16.48$, and $11.34 \$ \mathrm{kgH}_{2}^{-1}$. The investigated temperature and $\mathrm{H}_{2}$ permeance ranges of 483 to $543 \mathrm{~K}$ and $5 \times 10^{-7}$ to $5 \times 10^{-5} \mathrm{~mol} \mathrm{~m}^{-2} \mathrm{~s}^{-1}$ $\mathrm{Pa}^{-1}$, respectively, are expressed on the log scale.

In all cases, the unit $\mathrm{H}_{2}$ production cost decreased as the temperature and $\mathrm{H}_{2}$ permeance increased, and the curvature of the contours was very pronounced in the $\mathrm{H}_{2}$ permeance range of $1 \times 10^{-5}$ to $5 \times 10^{-5} \mathrm{~mol} \mathrm{~m}^{-2}$ $\mathrm{s}^{-1} \mathrm{~Pa}^{-1}$ indicating the effect of the $\mathrm{H}_{2}$ permeance on the cost reduction. In addition, as the temperature increased, the curvature became more pronounced, indicating the importance of both temperature and $\mathrm{H}_{2}$ permeance for estimation of the unit $\mathrm{H}_{2}$ production cost. On the other hand, the unit $\mathrm{H}_{2}$ production cost also declined as the $\mathrm{H}_{2}$ production capacity increased, i.e., from the wider region of the blue color (lower cost) and moving down the positions of the contours.

In short, the distributions of the unit $\mathrm{H}_{2}$ production cost based on the $\mathrm{H}_{2}$ production capacity, temperature, and $\mathrm{H}_{2}$ permeance as technoeconomic parameters were simultaneously investigated and effects of these parameters were confirmed.

\subsection{Carbon footprint analysis (CFA)}

To investigate the environmental effect of $\mathrm{MCH}$ dehydrogenation in an MR compared to the a PBR, CFA was conducted to assess the unit $\mathrm{CO}_{2}$ emissions for a $\mathrm{H}_{2}$ production capacity of $30 \mathrm{~m}^{3} \mathrm{~h}^{-1}$ (Fig. 11). In a case of a PBR, a total unit $\mathrm{CO}_{2}$ emission of $3.866 \mathrm{kgCO}_{2} \mathrm{kgH}_{2}^{-1}$ was obtained. In more detail, the $\mathrm{CO}_{2}$ emissions from the reactor, heater, and compressor were $2.088,1.093$, and $0.685 \mathrm{kgCO}_{2} \mathrm{kgH}_{2}^{-1}$, respectively. In the case of the MR, a much lower total $\mathrm{CO}_{2}$ emission of $3.022 \mathrm{kgCO}_{2}$ $\mathrm{kgH}_{2}^{-1}$ was obtained, corresponding to a reduction of $21.8 \%$. In addition, all $\mathrm{CO}_{2}$ emissions from each part were reduced compared to those of a PBR: $2.027 \mathrm{kgCO}_{2} \mathrm{kgH}_{2}^{-1}$ for the reactor; $0.819 \mathrm{kgCO}_{2} \mathrm{kgH}_{2}^{-1}$ for the heater; and $0.176 \mathrm{kgCO}_{2} \mathrm{kgH}_{2}^{-1}$ for the compressor; corresponding to cost reductions of $2.92,25.1$, and $74.3 \%$ for the reactor, heater, and compressor, respectively. These cost reductions in an MR were derived from the lower heat demand, less reactant, and purer product stream from the reactor. These results confirm the environmental feasibility of MCH dehydrogenation in an MR.

\section{Conclusions}

Methylcyclohexane (MCH) dehydrogenation in both a packed-bed reactor (PBR) and a membrane reactor (MR) was technically and economically investigated. Based on process simulation, economic analyses of the itemized cost estimation, sensitivity analysis (SA), and scenario analysis were carried out to investigate economic feasibility of $\mathrm{MCH}$ dehydrogenation in an MR. From the itemized cost estimation, unit $\mathrm{H}_{2}$ production costs of $11.76,9.50,8.50$, and $8.08 \$ \mathrm{kgH}_{2}^{-1}$ for the PBR and 9.37, 7.43, 6.58, and $6.23 \$ \mathrm{kgH}_{2}^{-1}$ for an MR were obtained for $\mathrm{H}_{2}$ production capacities of $30,100,300$, and $700 \mathrm{~m}^{3} \mathrm{~h}^{-1}$, respectively, clearly showing the cost effectiveness of an MR. The reactants, labor, and natural gas were identified as key economic parameters for all $\mathrm{H}_{2}$ production capacities for both types of reactors. To investigate the effects of the $\mathrm{H}_{2}$ production capacity, temperature, and $\mathrm{H}_{2}$ permeance as techno-economic parameters, scenario analyses were carried out. The variation of the unit $\mathrm{H}_{2}$ production costs for $\mathrm{H}_{2}$ production capacities of 30 to $700 \mathrm{~m}^{3} \mathrm{~h}^{-1}$ was evaluated at temperatures of 483,513 , and $543 \mathrm{~K}$, and permeances of $5 \times 10^{-7}, 5 \times 10^{-6}$, and $5 \times 10^{-5} \mathrm{~mol} \mathrm{~m}^{-2} \mathrm{~s}^{-1} \mathrm{~Pa}^{-1}$, clearly showing that economy of scale and $33.5 \%$ cost reduction could be achieved at the highest temperature and $\mathrm{H}_{2}$ permeance. The effect of temperature on the unit $\mathrm{H}_{2}$ production costs for a $\mathrm{H}_{2}$ production capacity of $30 \mathrm{~m}^{3} \mathrm{~h}^{-1}$ was evaluated for temperatures of 483 to $543 \mathrm{~K}$ and permeances of $5 \times 10^{-7}, 5 \times 10^{-6}$, and $5 \times 10^{-5} \mathrm{~mol} \mathrm{~m}^{-2} \mathrm{~s}^{-1} \mathrm{~Pa}^{-1}$. A very high cost reduction of $76.7 \%$ was achieved between 483 and $543 \mathrm{~K}$, demonstrating the importance of temperature in endothermic reactions such as $\mathrm{MCH}$ dehydrogenation. The effect of the $\mathrm{H}_{2}$ permeance on the unit $\mathrm{H}_{2}$ production cost was also investigated at temperatures of 483, 513 , and $543 \mathrm{~K}$ for the $\mathrm{H}_{2}$ production capacity of $30 \mathrm{~m}^{3} \mathrm{~h}^{-1}$. Similar to the effects of temperature, a dramatic cost reduction of $60.9 \%$ was achieved for permeances between $5 \times 10^{-7}$ and $5 \times 10^{-4} \mathrm{~mol} \mathrm{~m}^{-2} \mathrm{~s}^{-1}$ $\mathrm{Pa}^{-1}$, and this cost reduction declined as the temperature increased, showing that high $\mathrm{H}_{2}$ permeance can enable a reduction of the required heat. Furthermore, comprehensive scenario analysis of the overall effects of the parameters on the unit $\mathrm{H}_{2}$ production cost at temperatures of 483 to $543 \mathrm{~K}$, permeances of $5 \times 10^{-7}$ to $5 \times 10^{-5} \mathrm{~mol} \mathrm{~m}^{-2} \mathrm{~s}^{-1} \mathrm{~Pa}^{-1}$, and for $\mathrm{H}_{2}$ production capacities of $30,100,300$, and $700 \mathrm{~m}^{3} \mathrm{~h}^{-1}$ were conducted to generate color map and contour plots. Notably, within the $\mathrm{H}_{2}$ permeance range of $1 \times 10^{-5}$ to $5 \times 10^{-5} \mathrm{~mol} \mathrm{~m}^{-2} \mathrm{~s}^{-1} \mathrm{~Pa}^{-1}$ and from

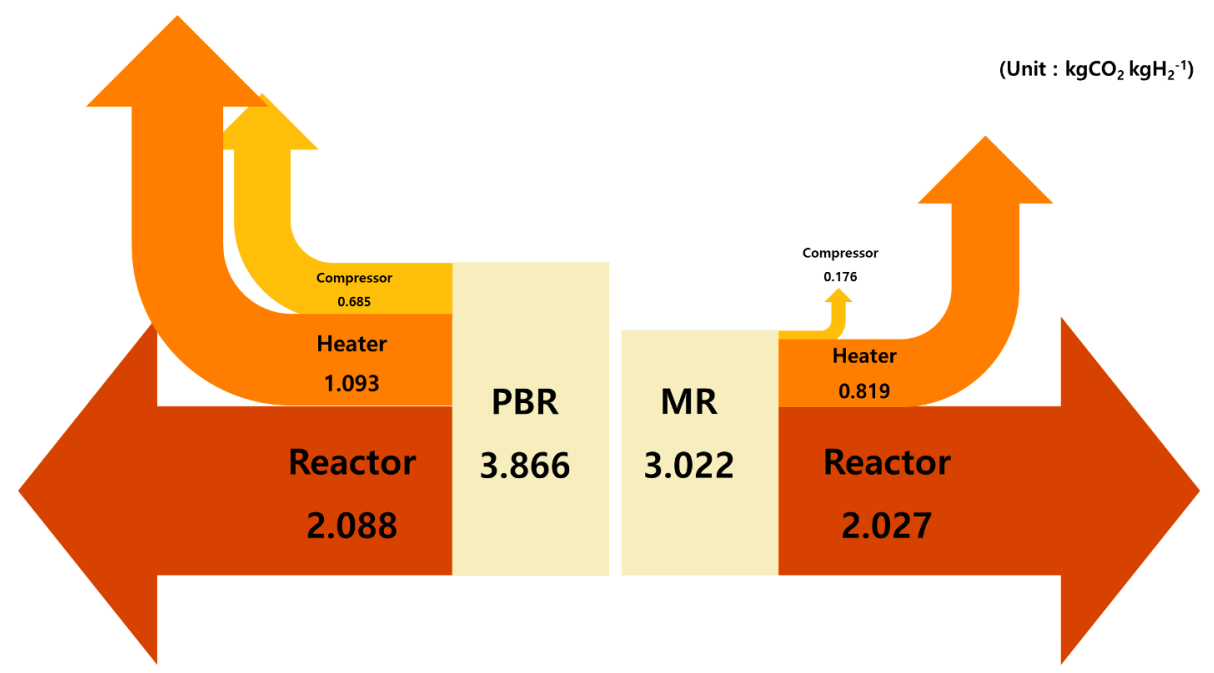

Fig. 11. $\mathrm{CO}_{2}$ flow diagrams of $\mathrm{MCH}$ dehydrogenation for a $\mathrm{PBR}$ and an $\mathrm{MR}$ based on carbon footprint analysis (CFA). 
a temperature of $513 \mathrm{~K}$, a dramatic cost reduction was obtained for all $\mathrm{H}_{2}$ production capacities. Environmental evaluation based on carbon footprint analysis (CFA) indicated dramatic reduction of the total $\mathrm{CO}_{2}$ emission (by 21.8\%) for the MR. Conclusively, the economic and environmental feasibility of MCH dehydrogenation in an MR for the efficient and $\mathrm{CO}_{2}$-free $\mathrm{H}_{2}$ production process was confirmed, providing insightful and practical guidelines.

\section{CRediT authorship contribution statement}

Manhee Byun: Writing - original draft, Conceptualization, Formal analysis. Heehyang Kim: Writing - original draft, Data curation, Formal analysis. Changgwon Choe: Investigation, Methodology. Hankwon Lim: Conceptualization, Supervision, Project administration.

\section{Declaration of Competing Interest}

The authors declare that they have no known competing financial interests or personal relationships that could have appeared to influence the work reported in this paper.

\section{Acknowledgement}

This work was supported by the Korea Institute of Energy Technology Evaluation and Planning (KETEP) granted financial resource from the Ministry of Trade, Industry \& Energy, Republic of Korea (No. 20183010032380 and No. 20173030041290).

\section{References}

[1] Desantes JM, Molina S, Novella R, Lopez-Juarez M. Comparative global warming impact and NOx emissions of conventional and hydrogen automotive propulsion systems. Energy Convers Manage 2020;221:113137-45.

[2] Lian J, Zhang Y, Ma C, Yang Y, Chaima E. A review on recent sizing methodologies of hybrid renewable energy systems. Energy Convers Manage 2019;199: 112027-49.

[3] Ishaq H, Dincer I. Design and performance evaluation of a new biomass and solar based combined system with thermochemical hydrogen production. Energy Convers Manage 2019;196:395-409.

[4] Wang H, Lei Z, Zhang X, Zhou B, Peng J. A review of deep learning for renewable energy forcasting. Energy Convers Manage 2019;198:111799-814.

[5] Xu X, Hu W, Cao D, Huang Q, Liu W, Jacobson MZ, et al. Optimal operational strategy for an offgrid hybrid hydrogen/electricity refueling station powered by solar photovoltaics. J Power Sources 2020;451:227810-9.

[6] Tong X, Ovtar S, Brodersen K, Hendriksen PV, Chen M. Large-area solid oxide cells with $\mathrm{La}_{0.6} \mathrm{Sr}_{0.4} \mathrm{CoO}_{3-\delta}$ infiltrated oxygen electrodes for electricity generation and hydrogen production. J Power Sources 2020;451:227742-9.

[7] Salkuyeh YK, Saville BA, MacLean HL. Techno-economic analysis and life cycle assessment of hydrogen production from natural gas using current and emerging technologies. Int J Hydrogen Energy 2017:42:18894-909.

[8] Lee H, Kim A, Lee B, Lim H. Comparative numerical analysis for an efficient hydrogen production via a steam methane reforming with a packed-bed reactor, a membrane reactor, and a sorption-enhanced membrane reactor. Energy Convers Manage 2020;213:112839-46.

[9] Burhan M, Shahzad MW, Oh SJ, Ng KC. A pathway for sustainable conversion of sunlight to hydrogen using proposed compact CPV system. Energy Convers Manage 2018;165:102-12.

[10] Li Z, Yao Z, Haidry AA, Plecenik T, Grancic B, Roch T, et al. The effect of Nb doping on hydrogen gas sensing properties of capacitor-like Pt/Nb-TiO2/Pt hydrogen gas sensors. J Alloy Compd 2019;806:1052-9.

[11] Mohammadi A, Mehrpooya M. Techno-economic analysis of hydrogen production by solid oxide electrolyzer coupled with dish collector. Energy Convers Manage 2018;173:167-78.

[12] Murthy AP, Madhavan J, Murugan K. Recent advnaces in hydrogen evolution reaction catalysts on carbon/carbon-based supports in acid media. J Power Sources 2018;398:9-26.

[13] Arxer M del M, Calleja LEM. Hercules project: contributing to the development of the hydrogen infrastructure. J Power Sources 2007;171:224-7.

[14] Xie H, Yu Q, Lu H, Zhang Y, Zhang J, Qin Q. Thermodynamic study for hydrogen production from bio-oil via sorption-enhanced steam reforming: Comparison with conventional steam reforming. Int J Hydrogen Energy 2017;42:28718-31.

[15] Detchusananard T, Im-orb K, Ponpesh P, Arpornwichanop A. Biomass gasification integrated with CO2 capture processes for high-purity hydrogen production: process performance and energy and energy analysis. Energy Convers Manage 2018;171:1560-72.

[16] Voldsund M, Jordal K, Anantharaman R. Hydrogen production with $\mathrm{CO}_{2}$ capture. Int J Hydrogen Energy 2016;4:4696-992.
[17] Wang Y, Li G, Liu Z, Cui P, Zhu Z, Yang S. Techno-economic analysis of biomass-tohydrogen process in comparison with coal-to-hydrogen process. Energy 2019;185: 1063-75.

[18] Capellan-Perez I, Mediavilla M, de Castro C, Carpintero O, Miguel LJ. Fossil fuel depletion and socio-economic scenarios: an integrated approach. Energy 2014;77: 641-66.

[19] Hook M, Tang X. Depletion of fossil fuels and anthropogenic climate change-a review. Energy Policy 2013;52:797-809.

[20] Navarro MV, Plou J, Lpoez JM, Grasa G, Murillo R. Effect of oxidation-reduction cycles on steam-methane reforming kinetics over a nickel-based catalyst. Int J Hydrogen Energy 2019;44:12617-27.

[21] Wang Z, Li L, Zhang G. Life cycle greenhouse gas assessment of hydrogen production via chemical looping combustion thermally coupled steam reforming. J Cleaner Prod 2018;179:335-46.

[22] Bineli A, Tasic MB, Filho RM. Catalytic steam reforming of ethanol for hydrogen production: brief status. Chem Industry Chem Eng Quart 2016;22:327-32.

[23] Azenha CSR, Mateos-Pedreor C, Queiros S, Concepcion P, Mendes A. Innovative $\mathrm{ZrO}_{2}$-supported CuPd catalysts for the selective production of hydrogen from methanol steam reforming. Appl Catal B 2017;203:400-7.

[24] Laosiripojana N, Sangtongkitcharoen W, Assabumrungrat S. Catalytic steam reforming of ethane and propane over $\mathrm{CeO}_{2}$-doped $\mathrm{Ni} / \mathrm{Al}_{2} \mathrm{O}_{3}$ at SOFC temperature: improvement of resistance toward carbon formation by the redox property of doping $\mathrm{CeO}_{2}$. Fuel 2006;85:323-32.

[25] Amirabadi S, Kabiri S, Vakili R, Iranshashi D, Rahimpour MR. Differential evolution strategy for optimization of hydrogen production via coupling of methylcyclohexane dehydrogenation reaction and methanol synthesis process in a thermally coupled double membrane reactor. Ind Eng Chem Res 2013;52:1508-22.

[26] Zhang C, Liang X, Liu S. Hydrogen production by catalytic dehydrogenation of methylcyclohexane over Pt catalysts supported on pyrolytic waste tire char. Int J Hydrogen Energy 2011;36:8902-7.

[27] Obara S. Energy and exergy flows of a hydrogen supply chain with truck transportation of ammonia or methyl cyclohexane. Energy 2019;174:848-60.

[28] Shukla AA, Gosavi PV, Pande JV, Kumar VP, Chary KVR, Biniwale RB. Efficient hydrogen supply through catalytic dehydrogenation of methylcyclohexane over Pt/metal oxide catalysts. Int J Hydrogen Energy 2010;35:4020-6.

[29] Ali JK, Baiker A. Critical examination of equilibrium constants proposed for the methylcyclohexane dehydrogenation to toluene. Chem Eng Commun 2019;206: 125-34.

[30] Manabe S, Yabe T, Nakano A, Nagatake S, Higo T, Ogo S, et al. Theoretical investigation on structural effects of Pt-Mn catalyst on activity and selectivity for methylcyclohexane dehydrogenation. Chem Phys Lett 2018;711:73-6.

[31] Lin Y-M, Rei M-H. Study on the hydrogen production from methanol steam reforming in supported palladium membrane reactor. Catal Today 2001;67:77-84.

[32] Gallucci F, Fernandez E, Corengia P, Annaland M van S. Recent advances on membranes and membrane reactors for hydrogen production. Chem Eng Sci 2013; 92:40-66.

[33] Loreti G, Facci AL, Peters T, Ubertini S. Numerical modeling of an automotive derivative polymer electrolyte membrane fuel cell cogeneration system with selective membranes. Int J Hydrogen Energy 2019;44:4508-23.

[34] Chompupun T, Limtrakul S, Vatanatham T, Kanhari C, Ramachandra PA. Experiments, modeling and scaling-up of membrane reactors for hydrogen production via steam methane reforming. Chem Eng Process - Process Intens 2018; 134:124-40.

[35] Tong J, Matsumura Y. Effect of catalytic activity on methane steam reforming in hydrogen-permeable membrane reactor. Appl Catal A 2005;286:226-31.

[36] Marcoberardino GD, Binotti M, Manzolini G, Viviente JL, Arratibel A, Roses L, et al. Achievements of European projects on membrane reactor for hydrogen production. J Cleaner Prod 2017;161:1442-50.

[37] Kreuder H, Boeltken T, Cholewa M, Meier J, Pfeifer P, Dittmeyer R. Heat storage by the dehydrogenation of methylcyclohexane - experimental studies for the design of a microstructured membrane reactor. Int J Hydrogen Energy 2016;41:12082-92.

[38] Hatim MDI, Fazara MAU, Syarhabil AM, Riduwan F. Catalytic Dehydrogenation of Methylcyclohexane (MCH) to toluene in a palladium/alumina hollow fibre membrane reactor. Procedia Eng 2013;53:71-80.

[39] Li G, Niimi T, Kanezashi M, Yoshioka T, Tsuru T. Equilibrium shift of methylcyclohexane dehydrogenation in a thermally stable organosilica membrane reactor for high-purity hydrogen production. Int J Hydrogen Energy 2013;38: 15302-6.

[40] Chen Y-R, Tsuru T, Kang D-Y. Simulation and design of catalytic membrane reactor for hydrogen production via methylcyclohexane dehydrogenation. Int J Hydrogen Energy 2017; 42:26296-307.

[41] Ali JK, Baiker A. Dehydrogenation of methylcyclohexane to toluene in a pilot-scale membrane reactor. Appl Catal A 1997;155:41-57.

[42] Li G, Yada K, Kanezashi M, Yoshioka T, Tsuru T. Methylcyclohexane dehydrogenation in catalytic membrane reactors for efficient hydrogen production. Ind Eng Chem Res 2013;52:13325-32.

[43] Cholewa M, Zehner B, Kreuder H, Pfeifer P. Optimization of membrane area to catalyst mass in a microstructured membrane reactor for dehydrogenation of methylcyclohexane. Chem Eng Process - Process Intens 2018;125:325-33.

[44] Oda K, Akamatsu K, Sugawara T, Kikuchi R, Segawa A, Nakao S-I. Dehydrogenation of methylcyclohexane to produce high-purity hydrogen using membrane reactors with amorphous silica membranes. Ind Eng Chem Res 2010;49: 11287-93.

[45] Meng L, Yu X, Niimi T, Nagasawa H, Kanezashi M, Yoshioka T, et al. Methylcyclohexane dehydrogenation for hydrogen production via a bimodal catalytic membrane reactor. Reaction Eng Kinetics Catal 2015;61:1628-38. 
[46] Sunny A, Solomon PA, Aparna K. Syngas production from regasified liquefied natural gas and its simulation using Aspen HYSYS. J Nat Gas Sci Eng 2016;30: 176-81.

[47] Sarvar-Amini A, Sotudeh-Gharebagh R, Bashiri H, Mostoufi N, Haghtalab A. Sequential simulation of a fluidized bed membrane reactor for the steam methane reforming using ASPEN PLUS. Energy Fuels 2007;21:3593-8.

[48] Turton R, Bailie RC, Whiting WB, Shaeiwitz JA, Bhattacharyya D. Analysis, synthesis, and design of chemical processes. fourth ed. New Jersey: Pearson; 2013.

[49] Reuß M, Grube T, Robinius M, Preuster P, Wasserscheid P, Stolten D. Seasona storage and alternative carriers: a flexible hydrogen supply chain model. Appl Energy 2017;200:290-302.

[50] Yang C, Ogden J. Determining the lowest-cost hydrogen delivery mode. Int J Hydrogen Energy 2007;32:268-86.

[51] Hoffman Z. Simulation and economic evaluation of coal gasification with SETS reforming process for power production. MS thesis. Louisiana State University; 2005.

[52] Kim JH, Kim GE, Yoo SH. A valuation of the restoration of Hwangnyongsa Temple in South Korea. Sustainability 2018;10:369-75.

[53] https://www.alibaba.com/product-detail/99-min-benzenehexahydride-methylcyclohexane-rice_50035121710.html?spm=a2700.7724857. normalList.29.587c4a14vJIMpU [Last Accessed 3 March 2020].
[54] Song C, Liu Q, Ji N, Kansha Y, Tsutsumi A. Optimization of steam methane reforming coupled with pressure swing adsorption hydrogen production process by heat integration. Appl Energy 2015;154:392-401.

[55] Lee B, Chae H, Choi NH, Moon C, Moon S, Lim H. Economic evaluation with sensitivity and profitability analysis for hydrogen production from water electrolysis in Korea. Int J Hydrogen Energy 2017;42:6462-71.

[56] Havas D, Lin H. Optimal membranes for biogas upgrade by removing CO2: high permeance or high selectivity? Sep Sci Technol 2017;52:186-96.

[57] http://www.citygas.or.kr/info/charge.jsp [Last Accessed 3 March 2020].

[58] Kim BJ, Kim JW, Ko HM. Economic evaluation of domestic low-temperature water electrolysis hydrogen production. Trans Korean Hydrogen New Energy Society 2011;22:559-67.

[59] Lee S, Noh D-W, Oh D. Characterizing the difference between indirect and direct $\mathrm{CO}_{2}$ emissions: Evidence from Korean manufacturing industries, 2004-2010. Sustainability 2018;10:2711-26.

[60] Kayfeci M, Kecebas A, Bayat M. Hydrogen production. In: Calise F, D’Accadia MD, Santarelli M, Lanzini A, Ferrero D, editors. Solar Hydrogen Production. Academic Press; 2019. p. 45-83.

[61] Apostolou D, Xydis G. A literature review on hydrogen refuelling stations and infrastructure. Current status and future prospects. Renew Sustain Energy Rev 2019;113:109292-305. 